\title{
Dihomooxacalix[4]arene-Based Fluorescent Receptors for Anion and Organic Ion Pair Recognition
}

\author{
Alexandre S. Miranda ${ }^{1,2} \oplus$, Paula M. Marcos $1,3, * \mathbb{1}$, José R. Ascenso $4{ }^{\oplus}$, \\ Mário N. Berberan-Santos ${ }^{2}$, Rachel Schurhammer ${ }^{5}\left(\mathbb{D}\right.$, Neal Hickey ${ }^{6}$ and Silvano Geremia ${ }^{6}$ \\ 1 Centro de Química Estrutural, Faculdade de Ciências da Universidade de Lisboa, Edifício C8, \\ 1749-016 Lisboa, Portugal; miranda.m.alexandre@gmail.com \\ 2 IBB-Institute for Bioengineering and Biosciences, Instituto Superior Técnico, Universidade de Lisboa, \\ 1049-001 Lisboa, Portugal; berberan@tecnico.ulisboa.pt \\ 3 Faculdade de Farmácia da Universidade de Lisboa, Av. Prof. Gama Pinto, 1649-003 Lisboa, Portugal \\ 4 Instituto Superior Técnico, CQE, Complexo I, Av. Rovisco Pais, 1049-001 Lisboa, Portugal; \\ jose.ascenso@ist.utl.pt \\ 5 Laboratoire de Modélisation et Simulations Moléculaires, Université de Strasbourg, UMR 7140, \\ F-67000 Strasbourg, France; rschurhammer@unistra.fr \\ 6 Department of Chemical and Pharmaceutical Sciences, Centre of Excellence in Biocrystallography, \\ University of Trieste, via L. Giorgieri 1, 34127 Trieste, Italy; nhickey@units.it (N.H.); sgeremia@units.it (S.G.) \\ * Correspondence: pmmarcos@fc.ul.pt
}

Academic Editor: Renata Riva

Received: 11 September 2020; Accepted: 8 October 2020; Published: 14 October 2020

\begin{abstract}
Fluorescent dihomooxacalix[4]arene-based receptors $\mathbf{5 a - 5 c}$, bearing two naphthyl(thio)ureido groups at the lower rim via a butyl spacer, were synthesised and obtained in the cone conformation in solution. The X-ray crystal structures of 1,3- (5a) and 3,4-dinaphthylurea $(5 \mathbf{b})$ derivatives are reported. Their binding properties towards several anions of different geometries were assessed by ${ }^{1} \mathrm{H}-\mathrm{NMR}$, UV-Vis absorption and fluorescence titrations. Structural and energetic insights of the naphthylurea $\mathbf{5 a}$ and $\mathbf{5 b}$ complexes were also obtained using quantum mechanical calculations. The data showed that all receptors follow the same trend, the association constants increase with the anion basicity, and the strongest complexes were obtained with $\mathrm{F}^{-}$, followed by the oxoanions $\mathrm{AcO}^{-}$and $\mathrm{BzO}^{-}$. Proximal urea $5 \mathbf{b}$ is a better anion receptor compared to distal urea $\mathbf{5 a}$, and both are more efficient than thiourea $\mathbf{5 c}$. Compounds $\mathbf{5 a}$ and $\mathbf{5 b}$ were also investigated as heteroditopic receptors for biologically relevant alkylammonium salts, such as the neurotransmitter $\gamma$-aminobutyric acid (GABA. $\mathrm{HCl}$ ) and the betaine deoxycarnitine. $\mathrm{HCl}$. Chiral recognition towards the guest sec-butylamine. $\mathrm{HCl}$ was also tested, and a 5:2 selectivity for $(R)$-sec- $\mathrm{BuNH}_{3}{ }^{+} \cdot \mathrm{Cl}^{-}$towards $(P)$ or $(M)$ enantiomers of the inherently chiral receptor 5 a was shown. Based on DFT calculations, the complex $\left[(S)-\sec -\mathrm{BuNH}_{3}{ }^{+} \cdot \mathrm{Cl}^{-} /(M)-5 \mathrm{a}\right]$ was indicated as the more stable.
\end{abstract}

Keywords: dihomooxacalix[4]arenes; naphthyl(thio)urea anion receptors; alkylammonium hydrochlorides; ditopic receptors; chiral recognition; NMR studies; UV-Vis absorption studies; fluorescence studies; X-ray diffraction; DFT calculations

\section{Introduction}

Calixarenes are among the most versatile macrocyclic compounds studied in supramolecular chemistry owing to their structural features [1,2]. They can be functionalized at the upper and lower rims, and they possess a pre-organized cavity available in different sizes and conformations. As a result, these compounds have been largely exploited as ion receptors. 
Fluorescence spectroscopy, due to its high sensitivity, has been used for ion binding determination [3,4]. Fluorogenic moieties, such as naphthalene, anthracene and pyrene are among the most incorporated in the calixarene framework, leading to the development of fluorescent probes for anion and also ion-pair recognition. Examples of such fluorescent calix[4] arene [5-10], calix[5] arene [11] and calix[6]arene [12-14] receptors have been reported in the literature.

Anions play important roles in many biological and chemical systems, and also in the environment $[15,16]$. Synthetic anion receptors, namely calixarenes containing amide or (thio)urea groups interact exclusively through $\mathrm{H}$-bonding with the anions. The $\mathrm{NH}$ groups provide strong and directional hydrogen bonds, resulting in well preorganized receptors. Some of these hosts can also act as ditopic receptors, simultaneously binding both ions of a given salt $[17,18]$. These receptors combine different binding sites in the same molecule, such as hydrogen bonds and oxygen donor atoms, besides an aromatic cavity that can establish $\pi-\mathrm{CH}$ interactions with the counter cation.

As part of our on-going interest on the host-guest properties of substituted dihomooxacalix[4]arenes (calix[4]arene analogues in which one $\mathrm{CH}_{2}$ bridge is replaced by one $\mathrm{CH}_{2} \mathrm{OCH}_{2}$ group) with (thio)urea units [19-23], we have extended our research into the study of fluorescent receptors for anion [24] and ion-pair recognition. Thus, dihomooxacalix[4]arene-based fluorescent sensors bearing (thio)urea groups as a binding site and naphthalene moieties as a fluorophore unit were obtained for the first time. This paper describes the synthesis of three disubstituted dihomooxacalix[4]arenes containing naphthylurea (compounds $\mathbf{5 a}$ and $\mathbf{5 b}$ ) or naphthylthiourea (compound $\mathbf{5 c}$ ) residues at the 1,3- or 3,4-positions of the lower rim, via a butyl spacer. These derivatives were obtained in the cone conformation in solution, confirmed by NMR. The cone conformation was also observed in the solid state (for $\mathbf{5} \mathbf{a}$ and $\mathbf{5 b}$ ) by $\mathrm{X}$-ray diffraction. Their binding properties towards several relevant anions were assessed by proton NMR, UV-Vis absorption and fluorescence spectroscopy. The urea compounds $(\mathbf{5} \mathbf{a}$ and $\mathbf{5 b})$ were also tested as heteroditopic receptors for biologically relevant alkylammonium salts, such as the amino acid $\gamma$-aminobutyric acid (GABA $\cdot \mathrm{HCl}$ ) and the betaine deoxycarnitine. $\mathrm{HCl}$. GABA is an important neurotransmitter with inhibitory activity in mammal central nervous system. Deoxycarnitine results from enzymatic methylation of GABA, and as other betaines is used as an osmotic regulator in plants. Chiral recognition towards the chiral guest sec-butylamine. $\mathrm{HCl}$ was also investigated taking advantage of the intrinsic chirality of urea 5a. Computational studies were also performed to add further insight to the binding process.

\section{Results and Discussion}

\subsection{Synthesis and Structural Analysis}

A few years ago we reported the reaction of parent compound 1 with bromobutyronitrile and $\mathrm{K}_{2} \mathrm{CO}_{3}$ to afford, after chromatographic separation, the asymmetric 1,3-dicyanodihydroxy derivative $2 \mathbf{a}$ and the symmetric 3,4-dicyanodihydroxy derivative $\mathbf{2 b}$ [19]. Following this synthetic route (Scheme 1), we undertook a three-step procedure from both the majority and the minority products $\mathbf{2} \mathbf{a}$ and $\mathbf{2} \mathbf{b}$, respectively, obtaining in the last step naphthylurea $\mathbf{5 a}$ and naphthylthiourea $\mathbf{5 c}$ from the asymmetric diamine $4 a$ and naphthylurea $5 b$ from the symmetric $4 b$. Comparing the ion affinity of receptors $\mathbf{5 a}$ and $\mathbf{5 b}$, it is expected to obtain some insights about the role of the substitution pattern (distal vs. proximal) of the two ureido groups in a cooperative binding process.

The ${ }^{1} \mathrm{H}-\mathrm{NMR}$ spectra of inherently chiral receptors $\mathbf{5 a}$ and $\mathbf{5} \mathbf{c}$ in $\mathrm{CDCl}_{3}$ at room temperature show four singlets for the tert-butyl groups, five $\mathrm{AB}$ quartets for the $\mathrm{CH}_{2}$ bridge protons, four pairs of doublets for the aromatic protons of the calixarene skeleton, and two triplets and two singlets for the $\mathrm{NHa}$ and $\mathrm{NHb}$ protons, respectively. Beside these peaks, the spectra display also two triplets and several multiplets for the methyl and methylene protons of the $n$-butyl groups and butyl spacers, as well as for the aromatic protons of the naphthyl groups. The proton assignments were confirmed by COSY spectra. Receptors $\mathbf{5 a}$ and $\mathbf{5} \mathbf{c}$ were obtained in the cone conformation, as indicated by the three $\mathrm{ArCH}_{2} \mathrm{Ar}$ resonances in the range 29.5-30.8 ppm of the ${ }^{13} \mathrm{C}-\mathrm{NMR}$ spectra [25]. 


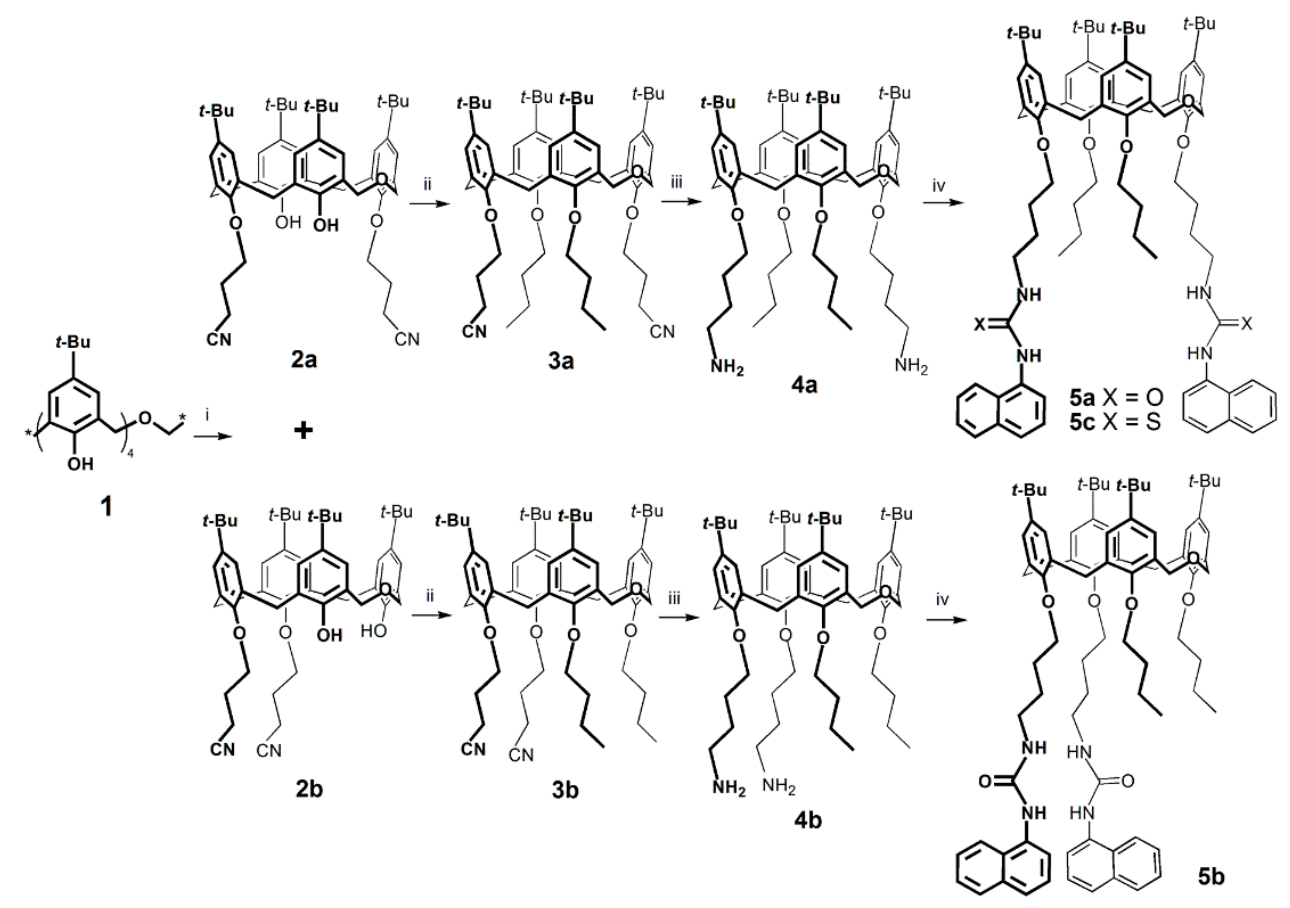

Scheme 1. Synthesis of naphthyl(thio)ureas 5a-5c. Reaction conditions: (i) $\mathrm{Br}\left(\mathrm{CH}_{2}\right)_{3} \mathrm{CN}, \mathrm{K}_{2} \mathrm{CO}_{3}, \mathrm{MeCN}$, $\Delta$; (ii) $n$-BuI, NaH, THF/DMF, $\Delta$; (iii) $\mathrm{NaBH}_{4} / \mathrm{CoCl}_{2}, \mathrm{MeOH}$, rt; (iv) Naph-NCX, $\mathrm{CHCl}_{3}$, rt.

In contrast, receptor $5 \mathbf{b}$ presents symmetric NMR spectra. The ${ }^{1} \mathrm{H}-\mathrm{NMR}$ spectrum displays two singlets for the tert-butyl groups, three $\mathrm{AB}$ quartets (in a 2:2:1 ratio) for the $\mathrm{CH}_{2}$ bridge protons, two pairs of doublets for the aromatic protons of the calixarene platform and one triplet and one singlet for the $\mathrm{NHa}$ and $\mathrm{NHb}$ protons, respectively, besides one triplet and several multiplets for the $\mathrm{CH}_{3}$ and $\mathrm{CH}_{2}$ protons of the butyl groups and spacers, and also for the aromatic protons of the naphthyl groups. The ${ }^{13} \mathrm{C}$-NMR spectrum exhibits two $\mathrm{ArCH}_{2} \mathrm{Ar}$ resonances at $30.3 \mathrm{ppm}$ (two carbon atoms) and at $30.5 \mathrm{ppm}$ (one carbon atom), indicating a cone conformation also for $\mathbf{5 b}$.

Small single crystals of naphthylureas $\mathbf{5 a}$ and $\mathbf{5 b}$ were analyzed using synchrotron radiation at $100 \mathrm{~K}$. The X-ray structures confirm that both $\mathbf{5 a}$ and $\mathbf{5 b}$ adopt the expected cone conformation, also in the solid state. The structural model of $\mathbf{5 a}$ clearly show that it is inherently chiral due to the 1,3-substitution pattern on the lower rim, which is asymmetric with respect to the dihomooxa bridge (Figure 1). As the space group is centrosymmetric, a racemic mixture of the two inherently chiral enantiomers is present in the crystals. With regard to the cone conformation, the planes of the two ureido-substituted phenyl rings $\mathbf{A}$ (connected to the dihomooxa bridge) and $\mathbf{C}$ make large dihedral angles of $124^{\circ}$ and $143^{\circ}$, respectively, with respect to the mean plane of the methylene bridging groups. Angles greater than $90^{\circ}$ indicate that the tert-butyl groups on the upper rims lean outwards from the centre of the cone (Figure 1). With respect to the butoxy-substituted phenyl rings, the plane of the one adjacent to the dihomooxa bridge (B) makes at a dihedral angle of $69^{\circ}$ with the mean plane of the methylene bridging groups, with the upper rim inclined inwards. The last phenyl ring (D) is tilted slightly outwards, with a dihedral angle of $99^{\circ}$.

Consistently with what we have previously observed for analogous calixarenes containing ureido or thioureido units on the lower rim, the two ureido groups form a bifurcated intramolecular $\mathrm{N}-\mathrm{H} \cdots \mathrm{O}$ hydrogen bond with $\mathrm{N} \cdots \mathrm{O}$ distances of $2.866 \AA$ and $2.895 \AA$. In the present case, the hydrogen bond is quite symmetric, indicative of a strong interaction. The mean planes formed by the NCON atoms of the urea moieties show a dihedral angle of $24^{\circ}\left(38^{\circ}\right.$ for the second orientation of the disordered naphthyl group of ring A), while the terminal naphthyl groups form dihedral angles of about $69^{\circ}$ (Ring A, $86^{\circ}$ for the second orientation) and $42^{\circ}$ (Ring C) with respect to their corresponding planar NCON groups. 


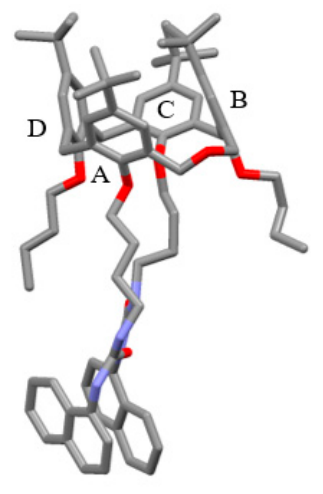

(a)

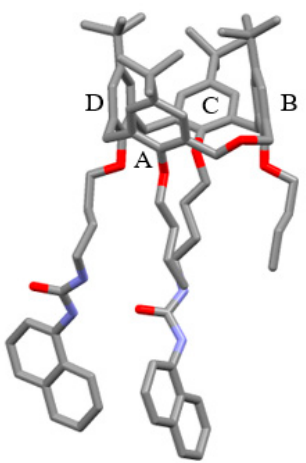

(b)

Figure 1. Solid state structures of (a) $5 \mathbf{a}$ and (b) $5 \mathbf{b}$. The structures, with very similar cone conformations, show significant differences in conformation of the lower rim substituents. The atomic species are represented in CPK colours. Hydrogen atoms are omitted for clarity.

The overall result is that the two naphthyl groups are almost parallel, forming a dihedral angle of about $4^{\circ}$ between their mean planes ( $7^{\circ}$ for the second orientation) (Figure 1$)$. The disordered naphthyl group (Ring $\mathbf{A}$ ) is oriented head-to-tail (head-to-head in the second orientation) with respect to the other naphthyl group (Ring $\mathbf{C}$ ). $\mathbf{5 b}$ adopts a similar cone conformation (Figure 1 ). In contrast to $\mathbf{5 a}$, the 3,4-substitution pattern on the lower rim maintains the $C_{s}$ point symmetry of the macrocycle. Comparison of the dihedral angles of the four phenyl rings A, B, C and D with the mean plane of the methylene bridging groups, indicate an analogous cone conformation for $\mathbf{5 a}$ and $\mathbf{5 b}$ (Table 1). Thus, only slight differences are evident for the $\mathrm{B}\left(14^{\circ}\right)$ and $\mathrm{D}\left(-11^{\circ}\right)$ rings. For comparison, we have previously reported two analogous dihomooxacalix[4]arenes with a 1,3-substitution pattern on the lower rim and which differ from 5a for the presence of two $p-\mathrm{CF}_{3}-$ phenylurea moieties [23] or unsubstituted phenylurea moieties [20] in place of the naphthyl urea groups. All structures with the 1,3-substitution pattern on the lower rim exhibit conformations which are comparable (Table 1). Thus, the small difference in the cone conformation observed for $5 \mathbf{b}$ can be attributed to the different substitution pattern. More significant difference between the two structures $\mathbf{5 a}$ and $\mathbf{5 b}$ are apparent in the relative orientations of the ureido substituents. The planes of the two naphthyl rings are almost perpendicular, with a dihedral angle of $88^{\circ}$, as opposed to the almost parallel situation found for 5a (Table S1). There are significant differences in the hydrogen bonds formed by the various molecules discussed here (Table S2). 5a and 5b both form strong bifurcated intramolecular and intermolecular hydrogen bond, while for the $p-\mathrm{CF}_{3}$-Phurea moieties the intramolecular bonds are quite asymmetric, and in the case of the Phurea moieties a solvent molecule is involved and breaks the intermolecular H-bond pattern.

Table 1. Comparison of cone conformations: Dihedral angles between corresponding aryl planes of the calixarene cones (A, B, C and D) and the mean planes of the bridging methylene carbon atoms for various dihomooxacalix[4]arenes.

\begin{tabular}{ccccc}
\hline & $\mathbf{A}\left(^{\circ}\right)$ & $\mathbf{B}\left(^{\circ}\right)$ & $\mathbf{C}\left(^{\circ}\right)$ & $\mathbf{D}\left(^{\circ}\right)$ \\
\hline $\mathbf{5 a}$ & $124^{\mathrm{a}}$ & 69 & $143^{\mathrm{a}}$ & 99 \\
$\mathbf{5 b}$ & 125 & 83 & $140^{\mathrm{a}}$ & $88^{\mathrm{a}}$ \\
$\mathrm{p}-\mathrm{CF}_{3}-\mathrm{Phurea}^{\mathrm{b}}$ & $125^{\mathrm{a}}$ & 66 & $131^{\mathrm{a}}$ & 101 \\
Phurea $^{\mathrm{c}}(\mathrm{I})$ & $123^{\mathrm{a}}$ & 64 & $133^{\mathrm{a}}$ & 100 \\
Phure $^{\mathrm{c}}$ (II) & $121^{\mathrm{a}}$ & 74 & $137^{\mathrm{a}}$ & 97 \\
\hline
\end{tabular}

${ }^{a}$ Ureido substituent on lower ring; ${ }^{\mathrm{b}}$ data taken from ref. $23{ }^{\mathrm{c}}$ data taken from ref. 20 for two independent molecules in the asymmetric unit. See Figure 2 and text for labelling of rings A, B, C and D. 
With regard to the crystal packing, in 5a each molecule acts as both an $N$-donor (on one ureido group) and an $\mathrm{O}$-acceptor (on the other ureido group) in the formation of two symmetry equivalent bifurcated intermolecular $\mathrm{N}-\mathrm{H} \cdots \mathrm{O}$ hydrogen bonds $(2.839 \AA$ and $2.974 \AA$ ) with two other molecules generated by the $22_{1}$ screw axis symmetry operation, thereby forming alternating intramolecular /intermolecular H-bond chains parallel to the crystallographic $b$-axis. Two inversion-related antiparallel chains are formed (Figure 2a). Each chain is composed of molecules with the same inherent chirality. Like $5 \mathbf{a}$, the urea group of $\mathbf{5 b}$ forms an intramolecular bifurcated H-bond with $\mathrm{N}$... O distances of $2.891 \AA$ and $2.975 \AA$, and two intermolecular bifurcated H-bonds with N...O distances of $2.909 \AA$ and $2.952 \AA$ (Figure 2 b). The intermolecular H-bonds are formed with molecules generated by the diagonal glide plane, forming antiparallel chains of H-bonds, parallel to the $a$-c cell diagonal.

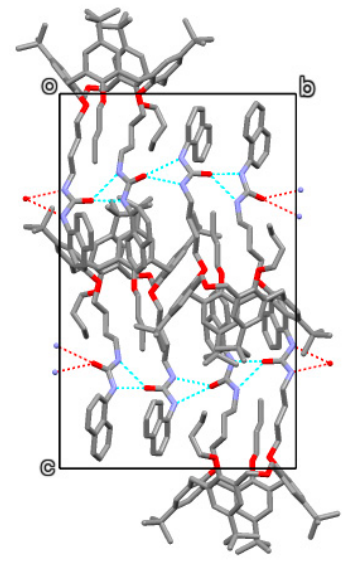

(a)

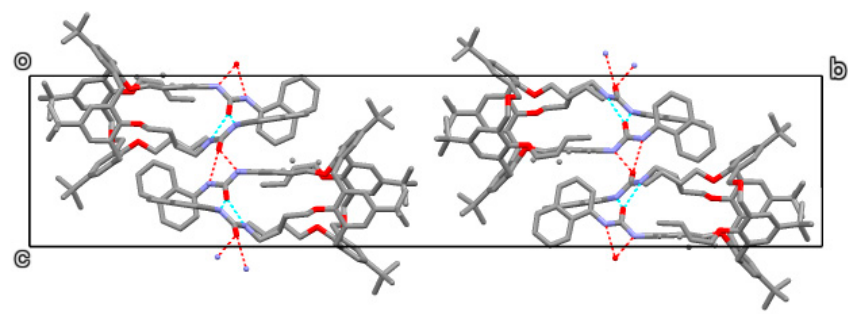

(b)

Figure 2. Crystal packing in the unit cells of (a) 5a and (b) $5 b$. In both cases the crystal packing is characterized by inversion-related antiparallel chains of bifurcated H-bonds. In $\mathbf{5 a}$, each molecule in the chain is generated by a 21 screw operation and the chains are parallel to the $b$-axis. Each chain is composed of molecules with the same chirality and the antiparallel chain is composed of opposite chirality. In $\mathbf{5 b}$, the molecules in each chain are generated by the glide planes and the chains are parallel to the $a-c$ cell diagonal. The atomic species are represented in CPK colours. Hydrogen atoms are omitted for clarity.

\subsection{Anion Complexation}

\subsubsection{Proton NMR Studies}

Complexation abilities of naphthyl(thio)ureas $\mathbf{5 a}-\mathbf{5} \mathbf{c}$ toward relevant anions of different geometries (spherical, trigonal planar and tetrahedral) were investigated in $\mathrm{CDCl}_{3}$ by proton NMR titrations with tetrabutylammonium (TBA) salts. The association constants (as log $K_{\text {ass }}$ ) were determined following the urea NH chemical shifts through the WinEQNMR2 program [26] and are reported in Table 2.

Table 2. Association constants $\left(\log K_{\text {ass }}\right){ }^{\text {a }}$ of dihomooxa naphthyl(thio)ureas $5 \mathbf{a}-5 \mathbf{c}$ in $\mathrm{CDCl}_{3}$ at $25{ }^{\circ} \mathrm{C}$.

\begin{tabular}{cccccccccc}
\hline & \multicolumn{3}{c}{ Spherical } & \multicolumn{3}{c}{ Trigonal Planar } & \multicolumn{2}{c}{ Tetrahedral } \\
\hline & $\mathrm{F}^{-}$ & $\mathrm{Cl}^{-}$ & $\mathrm{Br}^{-}$ & $\mathrm{I}^{-}$ & $\mathrm{NO}_{3}^{-}$ & $\mathrm{AcO}^{-}$ & $\mathrm{BzO}^{-}$ & $\mathrm{HSO}_{4}^{-}$ & $\mathrm{H}_{2} \mathrm{PO}_{4}^{-}$ \\
\hline I. Radius/ $\AA^{\mathrm{b}}$ & 1.33 & 1.81 & 1.96 & 2.20 & 1.79 & 2.32 & - & 1.90 & 2.00 \\
\hline $\mathbf{5 a}$ & 2.80 & 2.60 & 2.12 & 1.78 & 2.12 & 2.51 & 2.76 & 2.54 & 2.25 \\
$\mathbf{5 b}$ & 3.12 & 2.91 & 2.46 & 1.94 & 2.38 & 3.17 & 3.07 & 2.52 & 2.67 \\
$\mathbf{5} \mathbf{c}$ & 2.67 & 1.75 & 1.06 & 1.09 & 1.06 & 2.17 & 2.01 & 1.89 & 2.02 \\
\hline
\end{tabular}

\footnotetext{
${ }^{a}$ Estimated error < 10\%; ${ }^{b}$ Data quoted in Marcus, I. Ion Properties; Marcel Dekker: New York, pp. 50-51,1997.
} 
Significant downfield shifts of the NH protons were observed upon addition of TBA salts to the receptors, clearly indicating hydrogen bonding interactions between the (thio)urea groups and the anions, as illustrated in Figure 3 and Figure S1. Only one set of signals was observed during the titrations, showing fast exchange rate between the free and the complexed receptor on the NMR time scale at room temperature. The titration curves obtained (Figure S2) evidence the 1:1 complexes, this stoichiometry being also confirmed by Job plots (Figures S3 and S4).

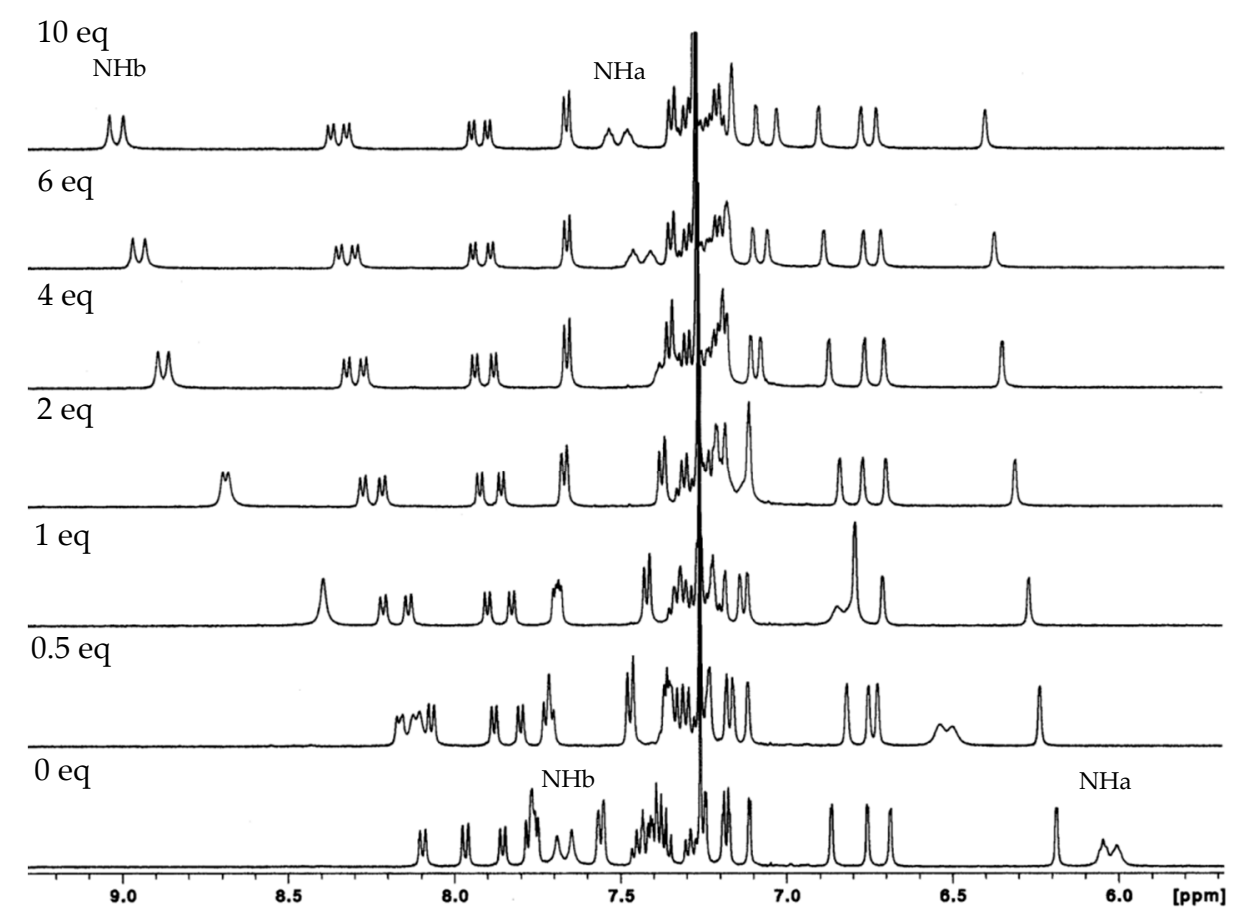

Figure 3. ${ }^{1} \mathrm{H}-\mathrm{NMR}$ partial spectra $\left(500 \mathrm{MHz}, \mathrm{CDCl}_{3}, 25^{\circ} \mathrm{C}\right)$ of Naph-urea 5 a with several equiv of TBA chloride.

The comparison between naphthylureas $\mathbf{5 a}$ and $\mathbf{5 b}$ allowed us to make some considerations about the cooperative action of the two ureido moieties on alternate vs. adjacent positions of the calixarene framework. The results displayed in Table 1 indicate that proximal naphthylurea $\mathbf{5 b}$ is a more efficient receptor for all the anions (except $\mathrm{HSO}_{4}{ }^{-}$). The association constants were, in average, $0.32 \mathrm{log}$ units higher than those obtained for distal naphthylurea $\mathbf{5 a}$ for the majority of the anions. In the case of $\mathrm{H}_{2} \mathrm{PO}_{4}{ }^{-}$and $\mathrm{AcO}^{-}$this enhancement was even higher (0.42 and $0.66 \log$ units, respectively). A similar behaviour was previously observed with distal and proximal calix[4]arene diphenylurea analogues [27]. Concerning the spherical halides, the data reveal that both ureas $\mathbf{5 a}$ and $\mathbf{5 b}$ form the strongest complexes with $\mathrm{F}^{-}\left(\log K_{\mathrm{ass}}=2.80\right.$ and 3.12 , respectively), and the association constants increase with the anion basicity. With regard to the trigonal planar and tetrahedral anions, urea $\mathbf{5 b}$ displays the same behaviour, showing the highest affinity for the carboxylate $\mathrm{AcO}^{-}$and the inorganic oxoanion $\mathrm{H}_{2} \mathrm{PO}_{4}^{-}$, respectively ( $\log K_{\text {ass }}=3.17$ and 2.67). In the case of urea $5 \mathbf{a}$, and as observed before with other dihomooxa bidentate $[19,23]$ and tetraurea receptors [21], there is a slight inversion of the basicity order $\left(\mathrm{AcO}^{-} / \mathrm{BzO}^{-}\right.$and $\left.\mathrm{H}_{2} \mathrm{PO}_{4}^{-} / \mathrm{HSO}_{4}{ }^{-}\right)$. $\pi$ stacking interactions may contribute to the increased binding of $\mathrm{BzO}^{-}$over that of $\mathrm{AcO}^{-}$.

The anion binding results reported in Table 2 also show that naphthylthiourea $5 \mathrm{c}$ is a weaker receptor than naphthylurea $\mathbf{5 a}$, despite the increased acidity of its $\mathrm{NH}$ groups. Thiourea $\mathbf{5 c}$ exhibits however a similar trend to $\mathbf{5 a}$, with the anions bound according to their basicity. The association constants were, in average, $0.84 \log$ units lower than those obtained for $5 \mathbf{a}$, except for the best bound anions $\mathrm{F}^{-}, \mathrm{AcO}^{-}$and $\mathrm{H}_{2} \mathrm{PO}_{4}{ }^{-}$, whose differences were smaller $\left(\Delta \log K_{\text {ass }}=0.13,0.34\right.$ and 0.23 , respectively). Similar results were reported before for different homooxacalixarene thiourea 
receptors $[21,28,29]$, as well as thioureido-calix[4] and [6]arene analogues [30,31]. This fact may be related to the larger size of sulfur atom, that destabilizes the cis-cis geometry required for anion binding, causing a lower preorganization and consequently a high energy demand of the thiourea groups compared to the urea ones [32].

The calixarene skeleton of symmetric urea $5 \mathbf{b}$ seems to undergo no conformational changes upon the addition of 8 equiv of the salts, as the tert-butyl and the aromatic protons show very small downfield or upfield chemical shift variations ( $\Delta \delta \leq 0.06$ and $0.03 \mathrm{ppm}$, respectively). By contrast, asymmetric urea $5 \mathbf{a}$ undergoes deeper conformational changes upon complexation. One of the four $t$-Bu groups experiences downfield variations from 0.05 to $0.20 \mathrm{ppm}$, while the other three display smaller upfield variations (from 0.01 to $0.14 \mathrm{ppm}$ ). The maximum chemical shifts were observed for $\mathrm{BzO}^{-}$anion. Concerning the aromatic protons, some of them are overlapped by other peaks and difficult to follow during all the titration. However, it is possible to observe that two of them show significant downfield variations, from 0.10 to $0.29 \mathrm{ppm}$, the highest chemical shifts being observed for $\mathrm{BzO}^{-}(0.29$ and $0.25 \mathrm{ppm})$.

\subsubsection{UV-Vis Absorption and Fluorescence Studies}

The interactions between naphthyl(thio)ureas $\mathbf{5 a - 5} \mathbf{c}$ and the previous anions as TBA salts have also been studied in dichloromethane by UV-Vis absorption and fluorescence titrations. Naphthylureas $\mathbf{5 a}$ and $\mathbf{5 b}$ showed identical behaviours with respect to anion complexation. Both ureas display absorption bands centred at approximately $283 \mathrm{~nm}$ in the absence of anions. These bands decrease in intensity upon addition of increasing amounts of $\mathrm{F}^{-}$, while a new one gradually appears at longer wavelength, reaching a maximum at approximately $315 \mathrm{~nm}$ (red shift of $32 \mathrm{~nm}$ ). Isosbestic points can also be observed, as for example in Figure 4a for receptor 5a. Concerning $\mathrm{Cl}^{-}, \mathrm{AcO}^{-}, \mathrm{BzO}^{-}$and $\mathrm{H}_{2} \mathrm{PO}_{4}^{-}$ anions similar absorption spectral changes were obtained (Figure S5), leading to red shifts of $20 \mathrm{~nm}$, but with no isosbestic points. Finally, additions of $\mathrm{Br}^{-}, \mathrm{NO}_{3}{ }^{-}$and $\mathrm{HSO}_{4}{ }^{-}$anions induced progressive increases of the absorption, but no shifts in their maxima were recorded (Figure S6). Naphthylthiourea $5 \mathrm{c}$ behaved differently for all the anions (Figure S7). In this case, the absorption band centred at $283 \mathrm{~nm}$ decreases as the anion concentration increases, presenting isosbestic points, but no significant shifts of its maximum.

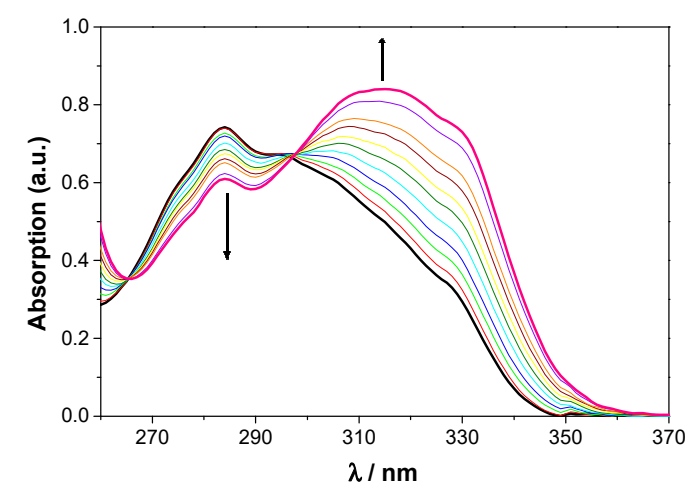

(a)

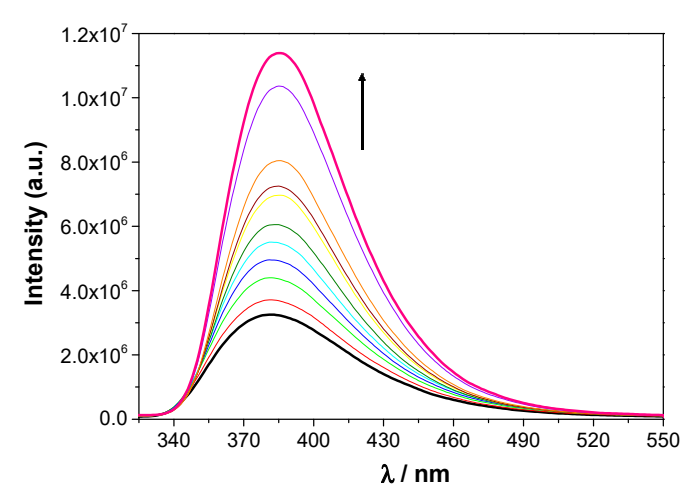

(b)

Figure 4. (a) Changes in the UV (a) and emission (b) spectra of Naph-urea $5 \mathbf{a}\left(5.0 \times 10^{-5} \mathrm{M}\right)$ upon addition of TBA $\mathrm{F}$ (up to 10 equiv.) in $\mathrm{CH}_{2} \mathrm{Cl}_{2}$. The arrows indicate the decreasing or increasing amounts of salt.

With regard to steady-state fluorescence studies, receptors $\mathbf{5 a}$ and $\mathbf{5 b}$ exhibit emission bands centred at approximately $380 \mathrm{~nm}$, characteristic of the naphthylurea groups [33]. Similar absorption and fluorescence spectra were reported in the literature for a ureido-calix[5]arene analogue [11]. No intramolecular excimer is observed in these fluorescence spectra, indicating the absence of $\pi-\pi^{*}$ stacking between the naphthyl moieties [33]. Both $\mathbf{5 a}$ and $\mathbf{5 b}$ display significant fluorescence lifetimes 
and quantum yields (Table 3). Successive additions of $\mathrm{F}^{-}, \mathrm{AcO}^{-}$and $\mathrm{H}_{2} \mathrm{PO}_{4}{ }^{-}$anions caused an increase of the emission intensity, as shown in Figure $4 \mathrm{~b}$. For $\mathrm{Br}^{-}, \mathrm{NO}_{3}{ }^{-}$and $\mathrm{HSO}_{4}{ }^{-}$anions this increase was less pronounced (Figure S8), and in the case of $\mathrm{Cl}^{-}$and $\mathrm{BzO}^{-}$(Figure S9) a quenching of the fluorescence intensity, with a concomitant decrease of the fluorescence quantum yield (Table 3), was observed. This decrease is stronger for asymmetric urea 5a. In the case of $\mathrm{Cl}^{-}$and $\mathbf{5 a}$, the fluorescence lifetime of the 1:1 complex shows a moderate decrease (about 2/3) with respect to the pristine receptor (Table 3), whereas the quantum yield drops by a factor of almost 4 . This implies the existence of a marked static quenching in the complex, with only a few configurations being able to emit. The same applies to $\mathbf{5 b}$, although to a lesser extent. In the case of $\mathrm{BzO}^{-}$, the quenching is similar with respect to both intensity and lifetimes (Table 3). It is seen that the quenching arises mainly from an increase in the nonradiative decay constant in the complex, where aromatic moieties of receptor and anion appear to interact. The fluorescence of thiourea $5 c$ could not be studied in detail as this receptor is unstable upon irradiation.

Table 3. Photophysical properties of Naphureas $5 \mathbf{a}$ and $\mathbf{5 b}$ in $\mathrm{CH}_{2} \mathrm{Cl}_{2}$ at $25^{\circ} \mathrm{C}$.

\begin{tabular}{|c|c|c|c|c|c|c|c|c|}
\hline & $\begin{array}{c}\lambda_{\max , \mathrm{abs}} \\
(\mathrm{nm})\end{array}$ & $\begin{array}{c}\varepsilon \\
\left(\mathrm{M}^{-1} \mathrm{~cm}^{-1}\right)\end{array}$ & $\begin{array}{c}\lambda_{\max , \mathrm{em}} \\
(\mathrm{nm})\end{array}$ & $\begin{array}{l}\text { Stokes Shift a } \\
(\mathrm{nm})\end{array}$ & $\begin{array}{c}\tau_{\mathrm{f}} \\
(\mathrm{ns})\end{array}$ & $\Phi_{\mathrm{F}}$ & $k_{\mathrm{r}}\left(\mathrm{ns}^{-1}\right)$ & $k_{\mathrm{nr}}\left(\mathrm{ns}^{-1}\right)$ \\
\hline $5 a$ & 283 & $1.5 \times 10^{4}$ & 382 & 99 & 8.93 & $0.31^{b}$ & 0.035 & 0.077 \\
\hline $5 \mathbf{a}+\mathrm{Cl}^{-}$ & 303 & $2.4 \times 10^{4}$ & 382 & 79 & 6.26 & $0.085^{b}$ & - & - \\
\hline $5 \mathrm{a}+\mathrm{BzO}^{-}$ & 303 & $2.0 \times 10^{4}$ & 382 & 79 & 1.98 & $0.048^{b}$ & 0.024 & 0.48 \\
\hline $5 b$ & 282 & $1.8 \times 10^{4}$ & 379 & 97 & 7.57 & $0.26^{\mathrm{b}}$ & 0.034 & 0.098 \\
\hline $5 b+\mathrm{Cl}^{-}$ & 302 & $2.3 \times 10^{4}$ & 379 & 77 & 6.63 & $0.16^{\mathrm{b}}$ & - & - \\
\hline $5 \mathbf{b}+\mathrm{BzO}^{-}$ & 302 & $1.7 \times 10^{4}$ & 379 & 77 & 3.27 & $0.078^{b}$ & 0.024 & 0.28 \\
\hline
\end{tabular}

Important spectral variations were observed for the three receptors in the presence of all the anions, allowing the calculation of the corresponding binding constants by absorption and emission (for the ureas) data (Table 4). The association constants are higher than those obtained by NMR (different concentration range), but follow the same trend. The more diluted solutions used in the UV/fluorescence titrations favour the dissociation of the salts, producing a higher concentration of the anions available for complexation and resulting in higher association constants [11]. Similar results were obtained by absorption and emission, in the same concentration range, showing that fluorescence can also be a useful method for the determination of the association constants. Proximal naphthylurea $\mathbf{5 b}$ is a slightly better receptor for all the anions (except $\mathrm{HSO}_{4}^{-}$) than distal urea $\mathbf{5 a}$, and $\mathrm{F}^{-}, \mathrm{AcO}^{-}$and $\mathrm{BzO}^{-}$are the best bound anions. Naphthylthiourea $5 \mathrm{c}$ displayed the same trend as its urea analogue, with the anions bound according to their basicity (Table 4). However, $\mathbf{5 c}$ is a weaker receptor, except in the cases of $\mathrm{F}^{-}, \mathrm{AcO}^{-}$and $\mathrm{H}_{2} \mathrm{PO}_{4}^{-}$anions, for which it showed similar $\log K_{\text {ass }}$ values.

Table 4. Association constants ( $\left.\log K_{\text {ass }}\right)^{\text {a }}$ of dihomooxa naphthyl(thio)ureas $5 \mathbf{a}-5 \mathbf{c}$ in $\mathrm{C}_{2} \mathrm{Cl}_{2}$ at $25{ }^{\circ} \mathrm{C}$.

\begin{tabular}{|c|c|c|c|c|c|c|c|c|c|}
\hline & & \multicolumn{3}{|c|}{ Spherical } & \multicolumn{3}{|c|}{ Trigonal Planar } & \multicolumn{2}{|c|}{ Tetrahedral } \\
\hline & & $\mathrm{F}^{-}$ & $\mathrm{Cl}^{-}$ & $\mathrm{Br}^{-}$ & $\mathrm{NO}_{3}^{-}$ & $\mathrm{AcO}^{-}$ & $\mathrm{BzO}^{-}$ & $\mathrm{HSO}_{4}^{-}$ & $\mathrm{H}_{2} \mathrm{PO}_{4}^{-}$ \\
\hline \multirow[t]{2}{*}{$5 a$} & Abs & 4.21 & 3.59 & 3.20 & 3.19 & 3.79 & 3.94 & 3.13 & 3.06 \\
\hline & Emi & 4.05 & 3.48 & 3.14 & 3.12 & 3.66 & 4.00 & 3.01 & 2.90 \\
\hline \multirow[t]{2}{*}{$5 b$} & Abs & 4.36 & 3.69 & 3.37 & 3.31 & 4.16 & 4.08 & 2.90 & 3.16 \\
\hline & Emi & 4.34 & 3.67 & 3.23 & 3.23 & 4.21 & 3.84 & 2.97 & 3.14 \\
\hline $5 c$ & Abs & 4.18 & 3.01 & 2.71 & 3.07 & 3.66 & 3.71 & 2.87 & 3.14 \\
\hline
\end{tabular}

\subsection{Organic Ion Pair Recognition}

Naphthylureas $\mathbf{5 a}$ and $\mathbf{5 b}$ have also been tested as ditopic receptors for $n$-propyl and $n$-butylammonium chlorides (Figure 5) in an exploratory study to estimate their ion pair binding efficiency. 


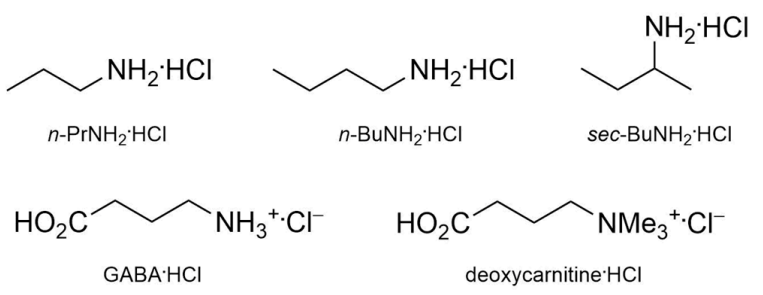

Figure 5. Structures of the ammonium hydrochloride guests studied.

Proton NMR titrations were performed by adding increasing amounts (up to two equiv.) of the salts to $\mathrm{CDCl}_{3}$ solutions of $\mathbf{5 a}$ and $\mathbf{5 b}$ at room temperature. The addition of the first salt aliquot produced doubling of the receptor peaks, and also a new set of signals corresponding to the guest bound to the host. Alkylammonium cation inclusion inside the dihomoxa cavity is shown by the appearance of high field resonances for the alkyl groups (from -1.32 to $-0.33 \mathrm{ppm}$ for $n-\mathrm{PrNH}_{3}{ }^{+}$ and from -1.32 to $0.26 \mathrm{ppm}$ for $n-\mathrm{BuNH}_{3}{ }^{+}$). In the case of receptor $5 \mathbf{a}$, due to its intrinsic chirality, the pairs of enantiotopic hydrogen atoms of the $\alpha$ - and $\beta-\mathrm{CH}_{2}$ groups of the included guest display chemically non-equivalent signals, as shown in Figure 6 for $n-\mathrm{BuNH}_{3}{ }^{+}$. On the other hand, chloride binding to the urea groups is demonstrated by the downfield shifts observed for all the NH protons $(\Delta \delta \geq 1 \mathrm{ppm})$, indicating anion complexation through hydrogen-bond interactions. These observations are compatible with a slow binding process on the NMR time scale. The percentages of complex formation and the corresponding association constants could thus be determined by direct integration of the peaks. The temperature was lowered to $263 \mathrm{~K} / 253 \mathrm{~K}$ to get a more sound integration of the signals, as they were slightly broad at room temperature. All host-guest pairs studied displayed percentages of complexation higher than $95 \%$ (corresponding to $K_{\text {ass }}>10^{9} \mathrm{M}^{-2}$ ), preventing a more accurate calculation of the association constants in chloroform.

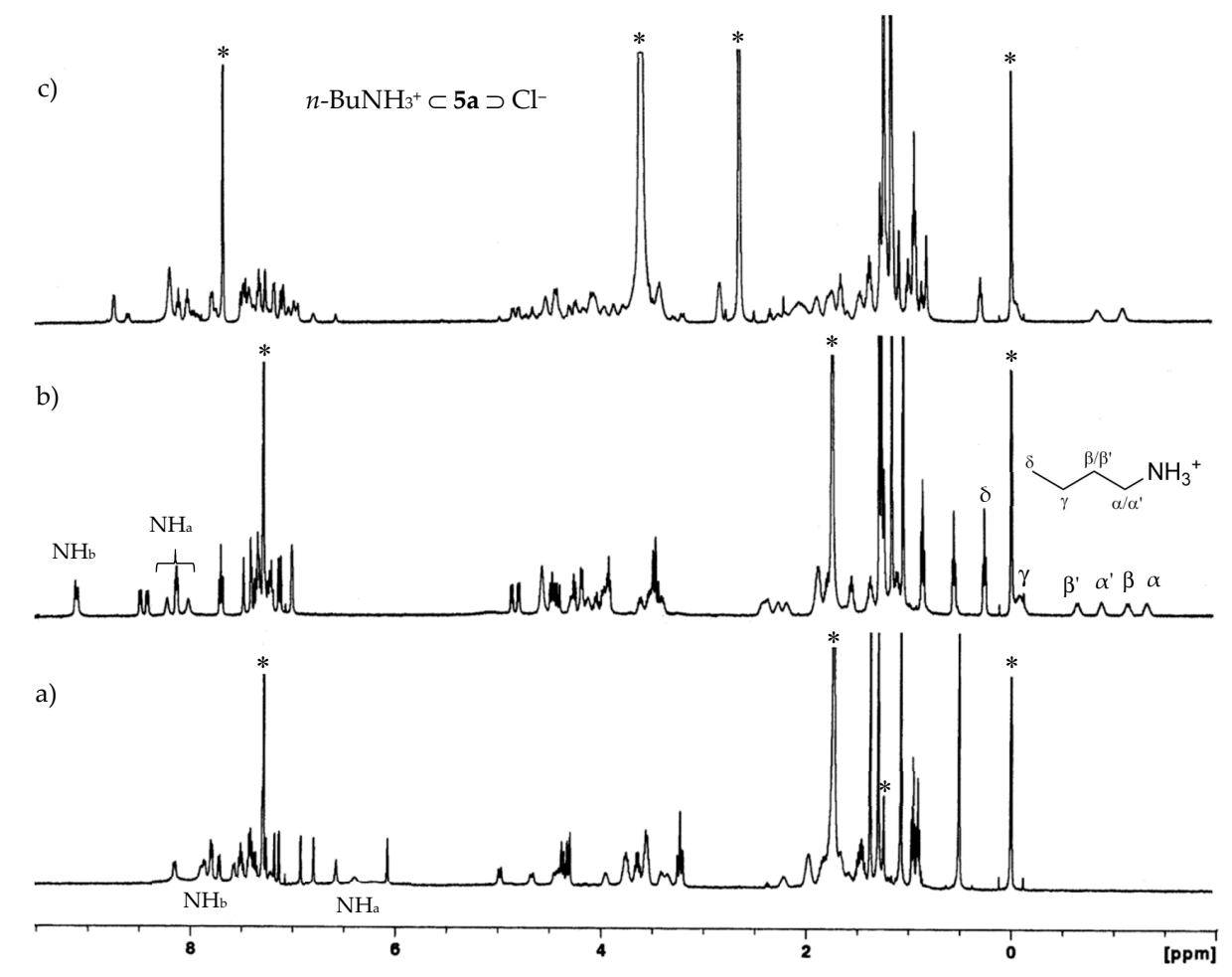

Figure 6. ${ }^{1} \mathrm{H}-\mathrm{NMR}$ spectra (500 MHz) of: (a) $[5 \mathbf{a}]=1.0 \mathrm{mM}$ at $253 \mathrm{~K}$ in $\mathrm{CDCl}_{3} ;(\mathbf{b})[\mathbf{5 a}]=\left[n-\mathrm{BuNH}_{2} \cdot \mathrm{HCl}\right]$ $=1 \mathrm{mM}$ at $253 \mathrm{~K}$ in $\mathrm{CDCl}_{3} ;$ (c) $[5 \mathrm{a}]=\left[n-\mathrm{BuNH}_{2} \cdot \mathrm{HCl}\right]=1 \mathrm{mM}$ at $243 \mathrm{~K}$ in $\mathrm{CDCl}_{3} / \mathrm{DMSO}-\mathrm{d}_{6}, 5: 1, v / v$.

* Denotes residual solvent signals. 
These titration experiments were repeated in a more competitive solvent $\left(\mathrm{CDCl}_{3} / \mathrm{DMSO}-\mathrm{d}_{6}, 5: 1\right)$ for the anion binding site and also that increases the ammonium solvation. It was necessary to lower the temperature until $273 \mathrm{~K}$ to observe the appearance of the peaks at the negative region of the ${ }^{1} \mathrm{H}$ NMR spectra, and to lower until $243 \mathrm{~K}$ to a better integration of the signals. Thus, the results obtained $\left(K_{\text {ass }}=18,000\right.$ and $29,000 \mathrm{M}^{-2}$, corresponding to $79 \%$ and $83 \%$ of complex formation for $n-\mathrm{PrNH}_{3}{ }^{+} \cdot \mathrm{Cl}^{-}$ with $\mathbf{5 a}$ and $\mathbf{5 b}$, respectively, and $K_{\mathrm{ass}}=10,000$ and $18,000 \mathrm{M}^{-2}$, corresponding to $73 \%$ and $79 \%$ of complex formation for $n-\mathrm{BuNH}_{3}{ }^{+} \cdot \mathrm{Cl}^{-}$with $\mathbf{5 a}$ and $\mathbf{5 b}$, respectively) show that receptor $5 \mathbf{b}$ is more efficient than $\mathbf{5 a}$ for both ion pairs, and the former guest is better bound than the latter by both receptors. This trend was also observed by the theoretical calculations (see below, Section 2.4). It is worth noting that in this solvent mixture the guests are less fixed within the aromatic cavity of the host, as indicated by the chemically equivalent signals for the $\alpha$ - and $\beta-\mathrm{CH}_{2}$ groups of the included guests (Figure 6c).

The binding affinities of ureas $\mathbf{5 a}$ and $\mathbf{5 b}$ were also extended to the aminoacid $\mathrm{GABA} \cdot \mathrm{HCl}$ and to the betaine deoxycarnitine. $\mathrm{HCl}$ (Figure 5) in a $\mathrm{CDCl}_{3} / \mathrm{CD}_{3} \mathrm{OD}(5: 1, v / v)$ solvent mixture. The former guest was first tested in its zwitterionic form at room temperature and at $233 \mathrm{~K}$. The NMR spectra remained almost unchanged after the addition of two equiv. of the guest, indicating no host-guest interaction. However, resonances at the negative region of the spectrum appeared when $\mathrm{GABA} \cdot \mathrm{HCl}$ was used, revealing the ammonium cation inclusion inside the aromatic cavity of the host (Figure 7).

For the inherently chiral receptor $5 \mathbf{a}$, four high field signals for the $\beta$ - and $\gamma-\mathrm{CH}_{2}$ protons of the guest were observed (Figure S10), in analogy with the alkylammonium chloride cases seen previously. To obtain a more reliable integration of the signals, the NMR spectra were registered at $233 \mathrm{~K}$. The data (81 and $88 \%$ of complex formation, corresponding to $K_{\mathrm{ass}}=22,000$ and $60,000 \mathrm{M}^{-2}$ for $\mathbf{5 a}$ and $\mathbf{5 b}$, respectively) indicate that receptor $\mathbf{5 b}$ is more efficient than $\mathbf{5 a}$, being in line with the previous anion and alkylammonium chloride binding results. Concerning the latter guest, no interaction at all was detected with both receptors, suggesting that the more bulky groups $\left(\mathrm{CH}_{3} \mathrm{vs}\right.$. $\left.\mathrm{H}\right)$ of the betaine guest prevent the inclusion inside the macrocycle cavity.

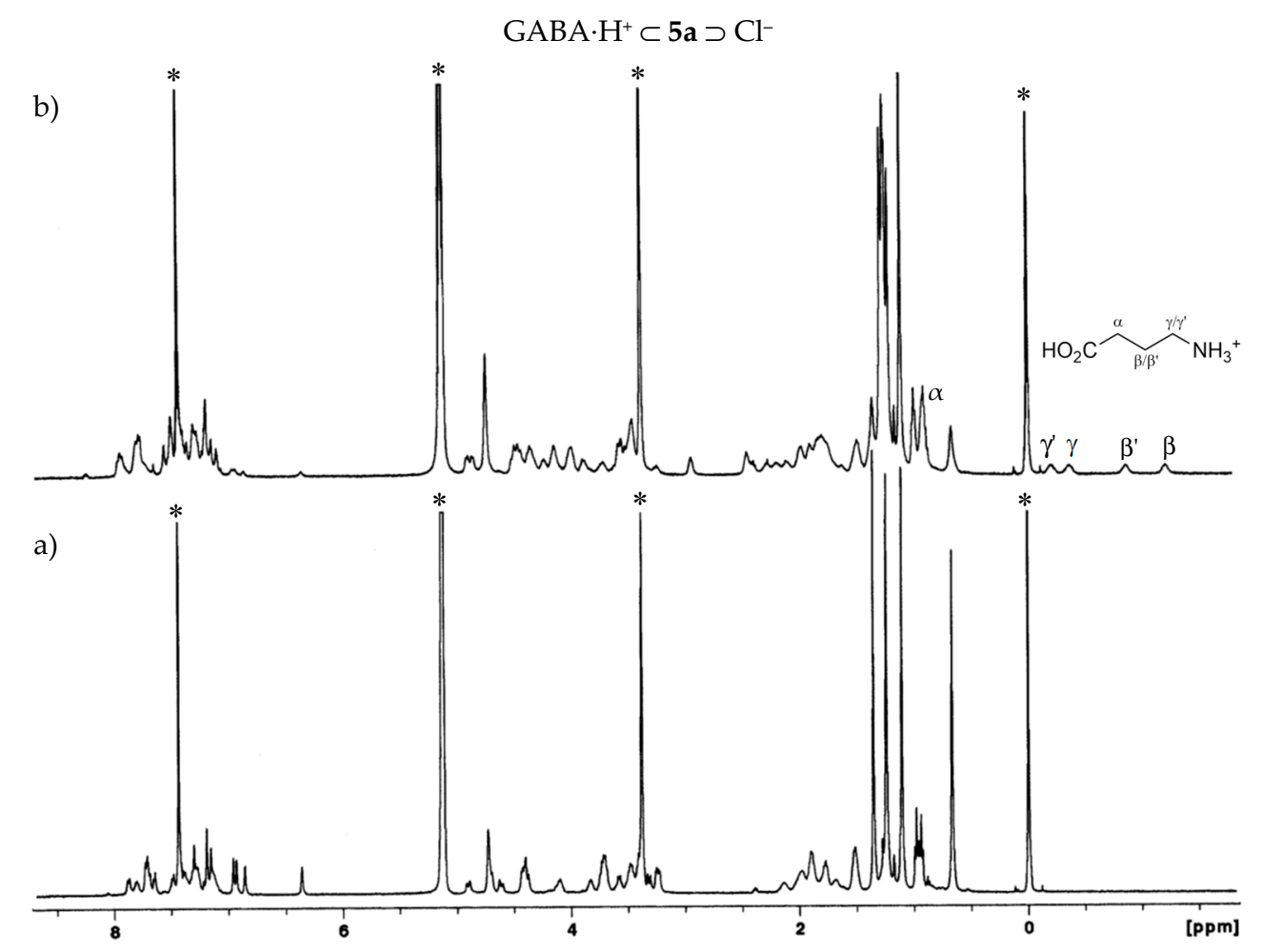

Figure 7. ${ }^{1} \mathrm{H}-\mathrm{NMR}$ spectra $\left(500 \mathrm{MHz}, 233 \mathrm{~K}, \mathrm{CDCl}_{3} / \mathrm{CD}_{3} \mathrm{OD}, 5: 1, v / v\right)$ of: (a) [5a] = $1.0 \mathrm{mM}$; (b) $[5 \mathrm{a}]=[\mathrm{GABA} \cdot \mathrm{HCl}]=1 \mathrm{mM} .{ }^{*}$ Denotes residual solvent signals. 
Chiral recognition towards racemic sec-butylamine $\mathrm{HCl}$ guest (Figure 5) was also investigated with both urea receptors. The NMR binding studies $\left(\mathrm{CDCl}_{3} / \mathrm{CD}_{3} \mathrm{OD}, 5: 1, v / v\right)$ performed at room temperature showed only a slight broadening of the host peaks. However, by lowering the temperature (until $223 \mathrm{~K}$ ) it was possible to see the appearance of upfield resonances belonging to the guest inside the aromatic cavity of the hosts. In the case of the achiral urea $5 \mathbf{b}$, the addition of one equiv. of the guest gives rise to the appearance of an asymmetric structure. For example, six singlets for the $t$-Bu groups, corresponding to the free (two peaks) and to the complexed receptor (four peaks) can be observed. Five high field resonances for the $\mathrm{sec}-\mathrm{BuNH}_{3}{ }^{+}$guest, including two multiplets for the diastereotopic $\beta$ methylene protons are also shown in the proton spectrum (Figure S11). The splitting of the $t$-Bu signals is not complete, preventing a very precise integration. However, a complex formation of approximately $70 \%$ could be determined. As reported before for the binding of sec-butylammonium ion with another achiral dihomooxacalixarene [34], the inclusion of the branched sec- $\mathrm{BuNH}_{3}{ }^{+}$ion into the dihomooxa cavity should restrict its free motion, producing this chiral complex. Concerning racemic urea 5a and in the same conditions as before, the proton NMR spectrum displays at least ten singlets for the $t$-Bu groups, four corresponding to the free host and the remaining ones corresponding to the two diastereotopic complexes formed $[\operatorname{host}(P) / \operatorname{guest}(R) \equiv \operatorname{host}(M) / \operatorname{guest}(S)+\operatorname{host}(P) / \operatorname{guest}(S) \equiv \operatorname{host}(M) / \operatorname{guest}(R)][35]$ (Figure 8). The percentage of complex formation is approximately of $65 \%$. The same situation $[\operatorname{host}(P) / \operatorname{guest}(R)+\operatorname{host}(M) /$ guest $(R)]$ was obtained when we used an enantiomerically pure guest $[(R)-(-)$-sec-butylamine. $\mathrm{HCl}$. Two sets of shielded resonances (8 signals instead of the expected 10 due to overlapping) for the sec-Bu group of the guest included into the cavity for the two diastereotopic complexes were seen in the high field region of the spectrum. A complete assignment of these peaks was obtained by a COSY spectrum (Figure S12). Their integration indicated a diastereomeric ratio of about 5:2.

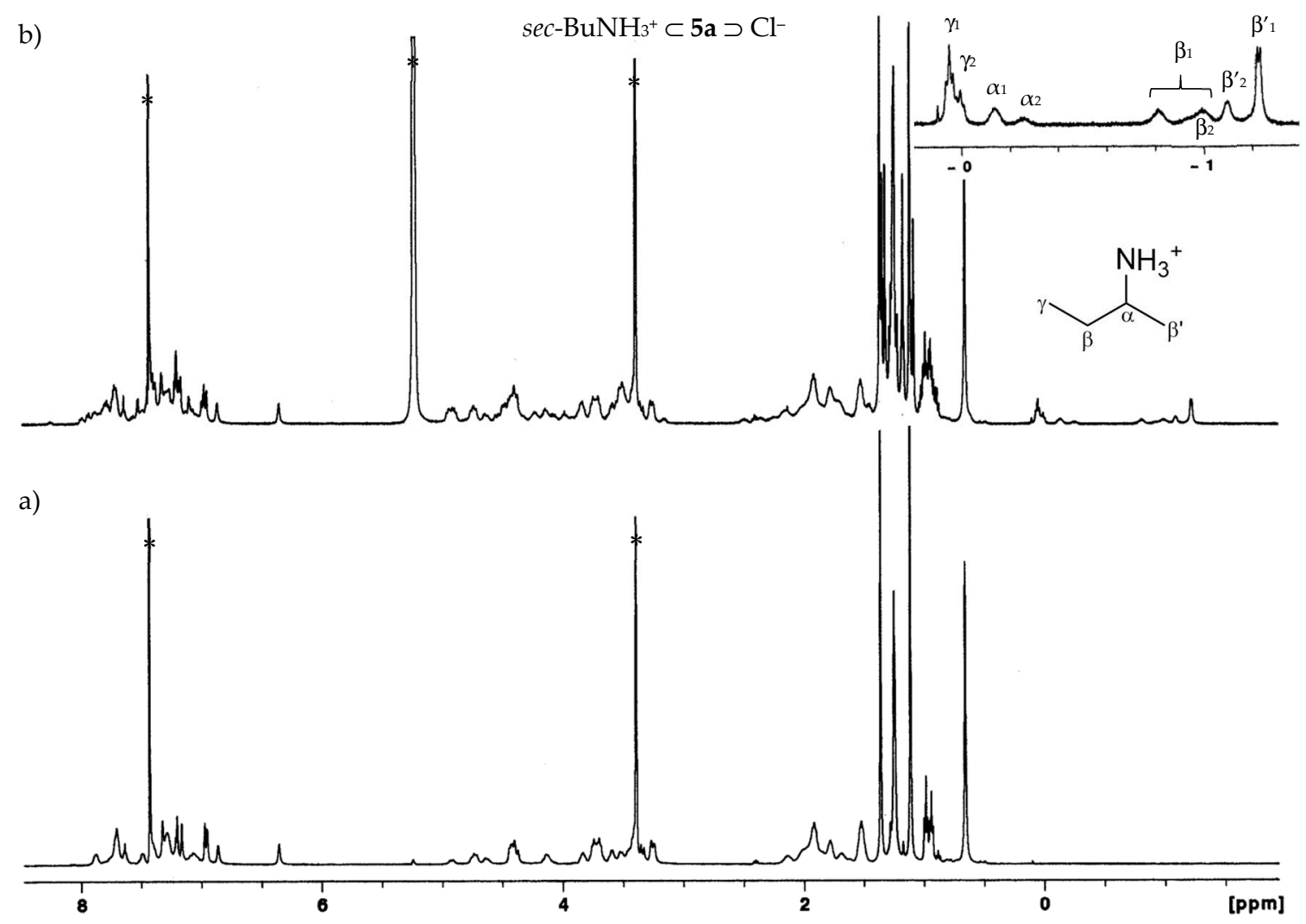

Figure 8. ${ }^{1} \mathrm{H}-\mathrm{NMR}$ spectra $\left(500 \mathrm{MHz}, 223 \mathrm{~K}, \mathrm{CDCl}_{3} / \mathrm{CD}_{3} \mathrm{OD}, 5: 1, v / v\right)$ of: (a) [5a] = $1.0 \mathrm{mM}$; (b) $[5 \mathrm{a}]=\left[\mathrm{sec}-\mathrm{BuNH}_{2} \cdot \mathrm{HCl}\right]=1 \mathrm{mM}$. Inset: 1 and 2 mean the two sets of signals for the $s$-Bu group of the guest inside the cavity for the two diastereotopic complexes formed. * Denotes residual solvent signals. 
By NMR is not possible to determine which complex [host $(P) /$ guest $(R)$ or host(M)/guest(R)] is more stable. Thus, DFT calculations were performed (see below) and showed an higher energy for the [host(M)/guest $(S)]$ complex. On this basis, the more intense NMR signals were assigned to the more stable complex $\left[(S)\right.$-sec- $\left.\mathrm{BuNH}_{3}{ }^{+} \cdot \mathrm{Cl}^{-} /(M)-5 \mathrm{a}\right]$, that can be directly transferred to its enantiomeric pair [host $(P) / \operatorname{guest}(R)]$, and a selectivity of about $5: 2$ could be deduced.

\subsection{Theoretical Studies}

In order to get further insights into the anion binding ability of $\mathbf{5 a}$ and $\mathbf{5 b}$, we performed quantum mechanical calculations on the complexed receptors with an extensive range of anions, including spherical halides $\left(\mathrm{F}^{-}\right.$vs. $\left.\mathrm{Cl}^{-}\right)$, trigonal $\left(\mathrm{AcO}^{-}\right.$vs. $\left.\mathrm{BzO}^{-}\right)$and tetrahedral $\left(\mathrm{HSO}_{4}^{-}\right.$vs. $\left.\mathrm{H}_{2} \mathrm{PO}_{4}^{-}\right)$. Heteroditopic complexation properties of $\mathbf{5 a}$ and $\mathbf{5 b}$ were also studied with alkylammonium salts, comparing $n-\mathrm{PrNH}_{3}{ }^{+} \cdot \mathrm{Cl}^{-}$and $n-\mathrm{BuNH}_{3}{ }^{+} \cdot \mathrm{Cl}^{-}$, and the affinity of the asymmetric host $5 \mathbf{a}$ for the chiral guest sec- $\mathrm{BuNH}_{3}{ }^{+} \cdot \mathrm{Cl}^{-}$was also investigated.

Each anion, whatever is its geometry, is bonded to the urea groups of $\mathbf{5 a}$ and $\mathbf{5 b}$ via four hydrogen bonds, as illustrated by snapshots of the optimized structures for fluoride, acetate and hydrogenophosphate anions in Figure 9. Similar structures were found for the other anions, as shown in Figure S13. The urea moieties always interact with the coordinated anions that sit in a hole formed by the four hydrogens of the $\mathrm{NH}$ groups. $\mathrm{AcO}^{-}$and $\mathrm{BzO}^{-}$are recognized via their carboxylate groups, while the methyl and benzyl groups point away from the binding cavity. The tetrahedral anions interact via their non protonated oxygens.

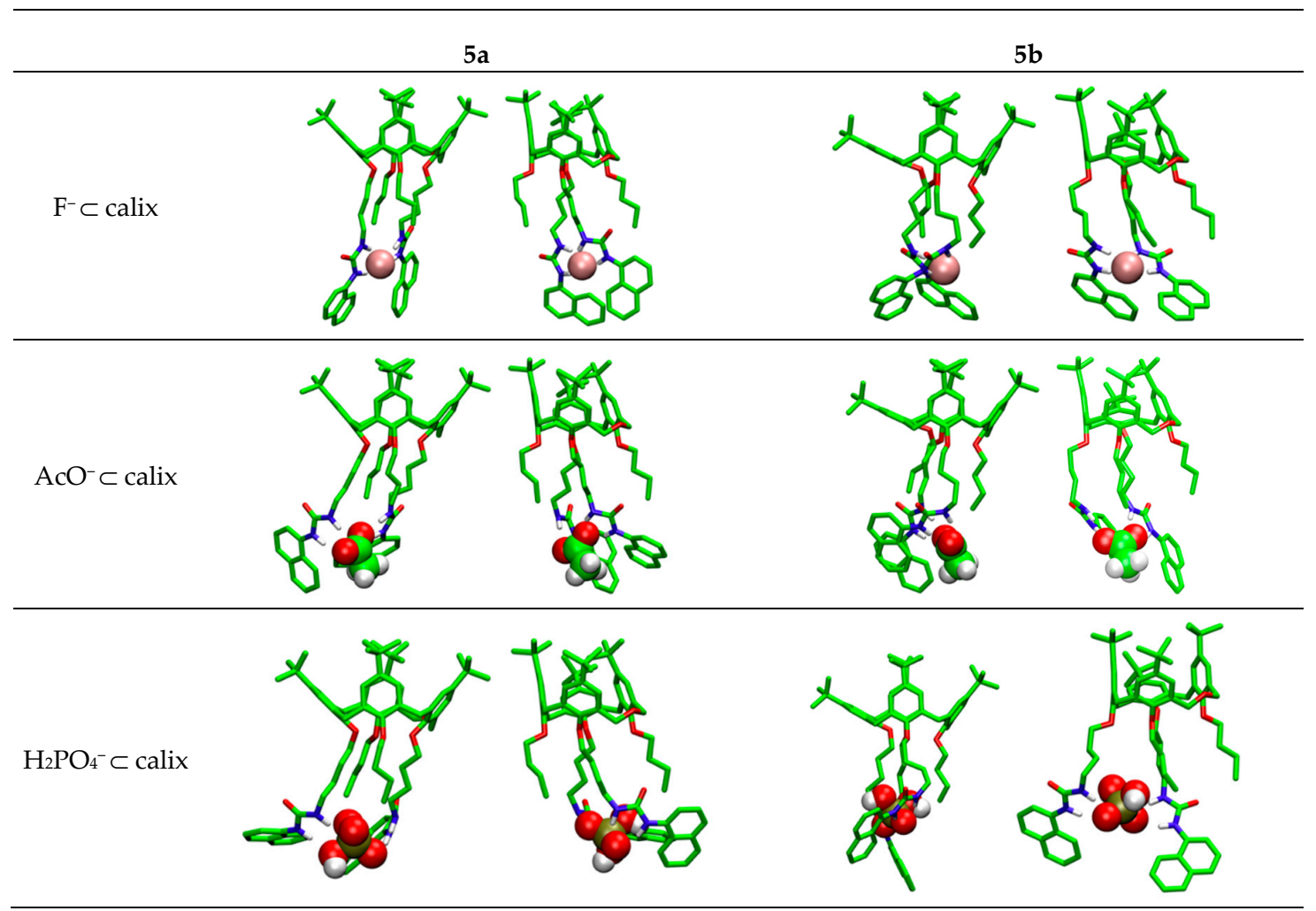

Figure 9. Structures of the $\mathrm{X}^{-} \subset \mathrm{Naph}$-urea complexes after QM optimization (orthogonal views). The atomic species are represented in CPK colours, except carbons that are in green.

The $\Delta E$ calculated complexation energies ( $\Delta E=E$ (complex) $-E$ (free ligand) $-E$ (ions), Table 5 and Table S3) nicely follow the association constants from Table 2. Naph-urea $\mathbf{5 b}$ is always a better receptor than Naph-urea $5 \mathrm{a}$, but the $\Delta E$ differences depend on the nature of the anions and go from

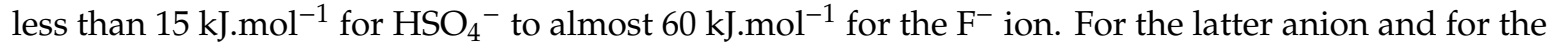


trigonal planar the energy discrimination between $\mathbf{5 a}$ and $\mathbf{5 b}$ is quite high (more than $50 \mathrm{~kJ} \cdot \mathrm{mol}^{-1}$ for $\mathrm{F}^{-}$and $\mathrm{BzO}^{-}$and $30 \mathrm{~kJ} \cdot \mathrm{mol}^{-1}$ for $\mathrm{AcO}^{-}$), while it is smaller (less than $17 \mathrm{~kJ} \cdot \mathrm{mol}^{-1}$ ) for $\mathrm{Cl}^{-}$and the tetrahedral anions. To analyse these differences the $\mathrm{H}$-bond distances between the receptor and the anions were measured (Table S4). As expected, comparing the anions within the same geometry group, the averaged $\mathrm{H}$-bond distances are correlated to the interaction energies: for the spherical $\mathrm{F}^{-} \mathrm{vs}^{-} \mathrm{Cl}^{-}$ anions the mean values are $1.747 \AA$ vs. $2.300 \AA$ and $1.746 \AA$ vs. $2.338 \AA$ for $5 \mathbf{a}$ and $5 \mathbf{b}$, respectively. This trend is also observed for the trigonal planar and tetrahedral ions. What is more surprising is the fact that the $\mathrm{H}$-bond distances are equal or shorter for $\mathbf{5 a}$, although $\mathbf{5 a}$ is always a weaker receptor than $\mathbf{5 b}$, for the same anion. Regarding the deformation energies of the calixarenes (i.e., the energy loss of the ligand) upon complexation (Table S5), it can be seen that the deformation is higher for 5a than for $5 \mathbf{b}$ with the spherical and trigonal planar anions $\left(\Delta_{\mathrm{def}} E=49\right.$ and $18 \mathrm{~kJ} \cdot \mathrm{mol}^{-1}$ for $\mathrm{F}^{-}$and $\mathrm{Cl}^{-}$, respectively, and around $40 \mathrm{~kJ} \cdot \mathrm{mol}^{-1}$ for $\mathrm{AcO}^{-}$and $\mathrm{BzO}^{-}$). These differences in the destabilisation of $5 \mathrm{a}$ may explain its lower complexation energies for these anions, although its $\mathrm{H}$-bond network is stronger. This tendency is inverted for the tetrahedral anions, the deformation being higher for $\mathbf{5 b}$ than for $\mathbf{5 a}$, although this difference is smaller $\left(\Delta_{\mathrm{def}} E \leq 13 \mathrm{~kJ} \cdot \mathrm{mol}^{-1}\right)$. In this case, $\mathbf{5 b}$ is much more destabilized (Table S5) than for the other groups of anions, presumably because the tetrahedral geometry of the anions is less adapted to the complexation by the two urea moieties.

Table 5. B3LYP/6-31G(d.p) + BG3BJ complexation energies $\Delta E\left(\right.$ in $\left.\mathrm{kJ} \cdot \mathrm{mol}^{-1}\right)$ for the guest-host complexes.

\begin{tabular}{|c|c|c|}
\hline \multicolumn{3}{|c|}{$\Delta E\left(\mathrm{~kJ} . \mathrm{mol}^{-1}\right)$} \\
\hline Host & $5 a$ & $5 b$ \\
\hline $\mathrm{F}^{-}$ & -498.9 & -557.1 \\
\hline $\mathrm{Cl}^{-}$ & -202.5 & -219.0 \\
\hline $\mathrm{AcO}^{-}$ & -261.5 & -291.4 \\
\hline $\mathrm{BzO}^{-}$ & -232.1 & -283.3 \\
\hline $\mathrm{HSO}_{4}^{-}$ & -192.3 & -206.2 \\
\hline $\mathrm{H}_{2} \mathrm{PO}_{4}^{-}$ & -220.6 & -236.6 \\
\hline$n-\mathrm{PrNH}_{3}{ }^{+} \cdot \mathrm{Cl}^{-}$ & -736.3 & -811.6 \\
\hline$n-\mathrm{BuNH}_{3}{ }^{+} \cdot \mathrm{Cl}^{-}$ & -656.5 & -709.5 \\
\hline$(R)-\sec -\mathrm{BuNH}_{3}{ }^{+} \cdot \mathrm{Cl}^{-} /(M)-\mathbf{5 a}$ & -704.1 & - \\
\hline$(S)-\mathrm{sec}-\mathrm{BuNH}_{3}{ }^{+} \cdot \mathrm{Cl}^{-} /(M)-5 \mathbf{a}$ & -712.4 & - \\
\hline$(R)-\mathrm{sec}-\mathrm{BuNH}_{3}{ }^{+} \cdot \mathrm{Cl}^{-} /(P)-\mathbf{5 a}$ & -691.1 & - \\
\hline$(S)-\mathrm{sec}-\mathrm{BuNH}_{3}+\cdot \mathrm{Cl}^{-} /(P)-\mathbf{5 a}$ & -695.4 & - \\
\hline
\end{tabular}

Concerning the heteroditopic complexation with the alkylammonium salts, the position of the chloride anion is the same than for the single anion complexes (see Figure 10). The H-bonding network is similar: $\mathrm{Cl}^{-}$interacts with the four hydrogen atoms of the urea groups with bond distances of about $2.3 \AA$ each. The alkylammonium cations are positioned in the centre of the upper rim of the calixarenes. The ammonium group is asymmetrically $\mathrm{H}$-bonded to the phenoxy oxygen atoms, as illustrated by the H-bond length given in Table S4. As $\mathrm{NH}_{3}{ }^{+}$does not perfectly suit with the topology of the macrocycle cavity, it always displays two short H-bonds (less than $1.9 \AA$ ) and a longer one (up to $2.8 \AA$ ). The bridging ether oxygen atom is never involved in these interactions. The interaction energies obtained also indicate that $5 \mathbf{b}$ is a better host than $5 \mathbf{a}$, and the $n$ - $\mathrm{PrNH}_{3}{ }^{+} \cdot \mathrm{Cl}^{-}$salt is better bound than the $n$ - $\mathrm{BuNH}_{3}{ }^{+} \cdot \mathrm{Cl}^{-}$one. Calculations with both enantiomers $(R)$ and $(S)$ of the chiral guest sec-BuNH${ }_{3}{ }^{+} \cdot \mathrm{Cl}^{-}$show no clear differences in the coordination mode of receptor $5 \mathbf{a}$, displaying however higher energy for the latter enantiomer $\left(\Delta E=8.3\right.$ and $4.3 \mathrm{~kJ} \cdot \mathrm{mol}^{-1}$ for $(M)$ and $(P)$ enantiomers of $5 \mathbf{a}$, respectively). The $(M)$-5a enantiomer leads to higher coordination energy than the $(P)-5 a$ one $(\Delta E=17$ and $13 \mathrm{~kJ} \cdot \mathrm{mol}^{-1}$ for $(S)$ and $(R)$ guests, respectively), indicating the $\left[(S)-\sec -\mathrm{BuNH}_{3}{ }^{+} \cdot \mathrm{Cl}^{-} /(M)-5 \mathrm{a}\right]$ complex as the most stable. 


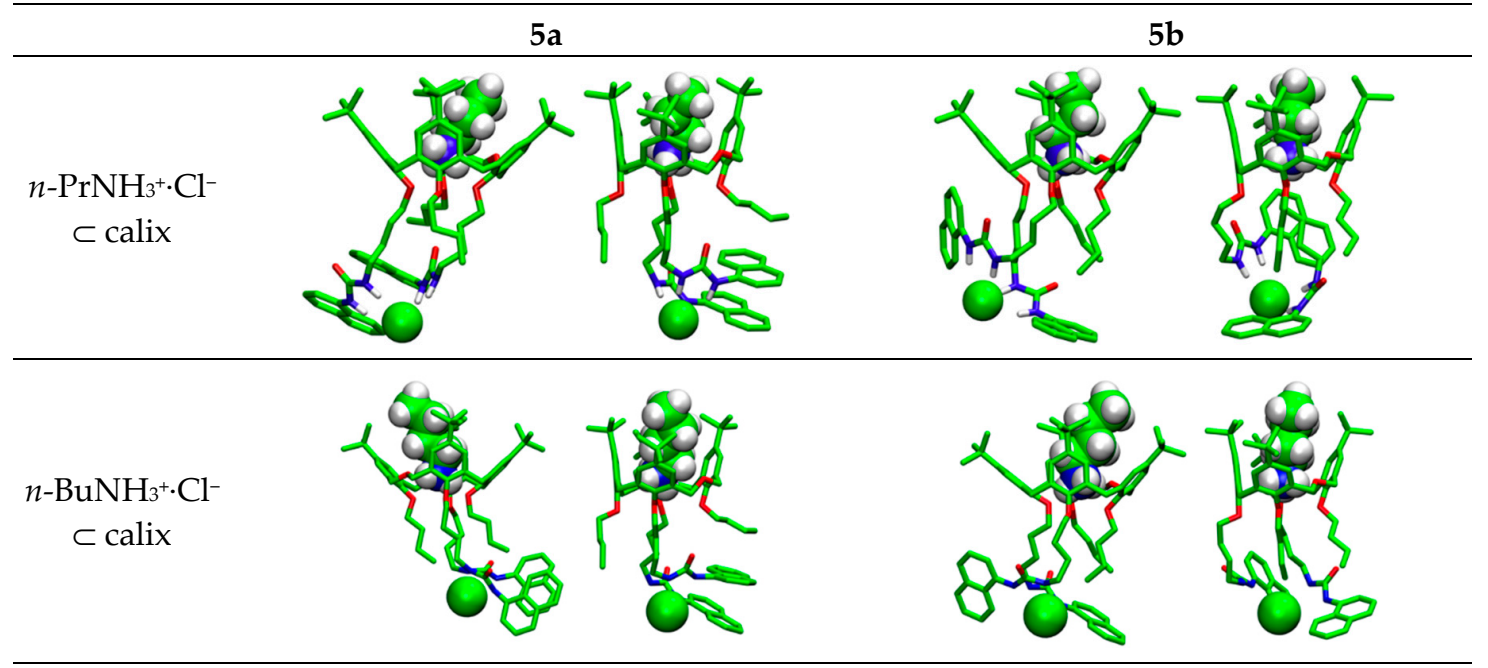

$(R)-\sec -\mathrm{BuNH}_{3}^{+} \subset \mathbf{5 a} \supset \mathrm{Cl}^{-}$

$(S)-\sec -\mathrm{BuNH}_{3}{ }^{+} \subset \mathbf{5 a} \supset \mathrm{Cl}^{-}$

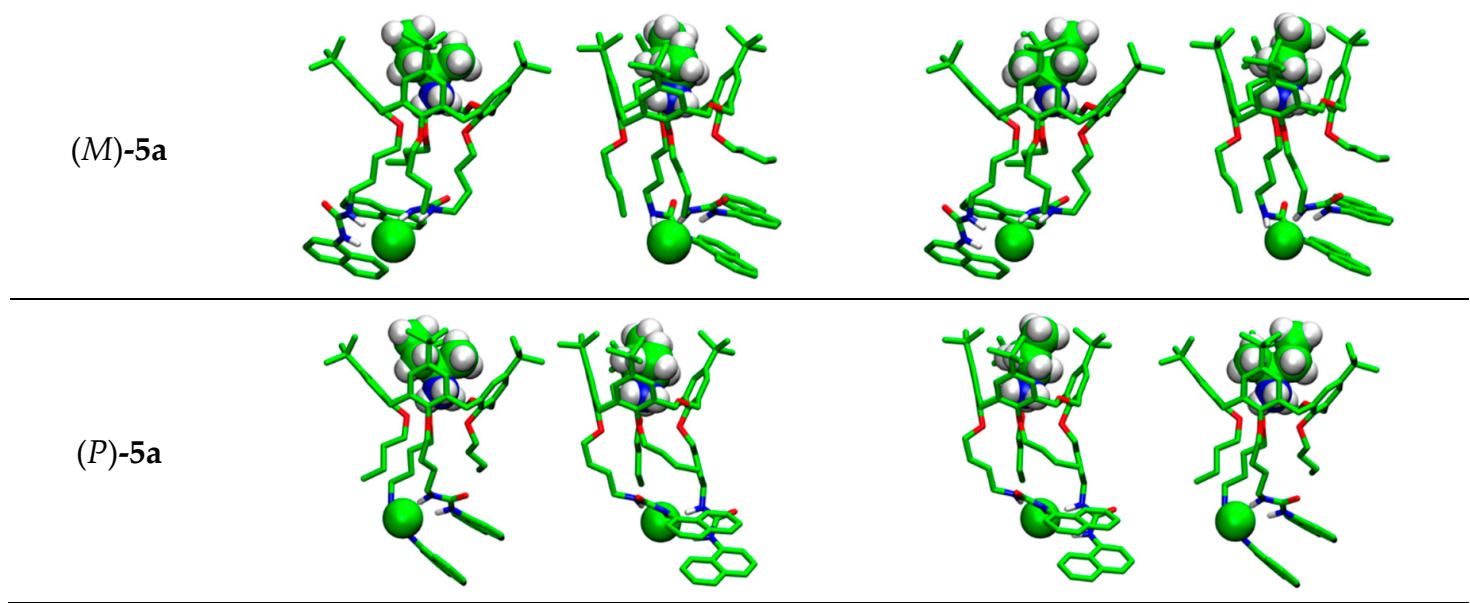

Figure 10. Structures of the $\mathrm{R}_{-\mathrm{NH}_{3}}{ }^{+} \subset$ calix $\supset \cap \mathrm{Cl}^{-}$complexes after QM optimization (orthogonal views). The atomic species are represented in CPK colours, except carbons that are in green.

\section{Materials and Methods}

\subsection{Synthesis}

\subsubsection{Procedure for the Synthesis of (thio)ureas $5 \mathbf{a}$ and $\mathbf{5 c}$}

To a solution of $4 \mathbf{a}$ [19] $(0.77 \mathrm{~g}, 0.83 \mathrm{mmol})$ in $\mathrm{CHCl}_{3}(30 \mathrm{~mL})$ was added $1.65 \mathrm{mmol}$ of naphthyl isocyanate or naphthyl isothiocyanate, respectively. The mixture was stirred at room temperature under $\mathrm{N}_{2}$ for $4 \mathrm{~h}$. Evaporation of the solvent yielded the crude products which were purified as described below.

7,13,19,25-Tetra-tert-butyl-27,29-bis[[(N'-1-naphthylureido)butyl]oxy]-28,30-dibutoxy-2,3-dihomo-3-oxacalix[4]arene (5a). Flash chromatography $\left(\mathrm{SiO}_{2}\right.$, eluent $\mathrm{CH}_{2} \mathrm{Cl}_{2} / \mathrm{MeOH}$, from 99.5:0.5 to 95:5) followed by recrystallization from $\mathrm{CH}_{2} \mathrm{Cl}_{2} / n$-hexane: it was obtained in $30 \%$ yield $(0.31 \mathrm{~g})$; m.p. $258-259{ }^{\circ} \mathrm{C}$; IR $(\mathrm{KBr}) 3314 \mathrm{~cm}^{-1}(\mathrm{NH}), 1638 \mathrm{~cm}^{-1}(\mathrm{CO}) ;{ }^{1} \mathrm{H}-\mathrm{NMR}\left(\mathrm{CDCl}_{3}, 500 \mathrm{MHz}\right) \delta 0.58,1.04,1.28,1.36[4 \mathrm{~s}, 36 \mathrm{H}$, $\left.\mathrm{C}\left(\mathrm{CH}_{3}\right)_{3}\right], 0.89,0.94\left(2 \mathrm{t}, 6 \mathrm{H}, J=7.45 \mathrm{~Hz}, \mathrm{CH}_{3}\right), 1.45\left(\mathrm{~m}, 4 \mathrm{H}, \mathrm{OCH}_{2} \mathrm{CH}_{2} \mathrm{CH}_{2} \mathrm{CH}_{3}\right), 1.64,1.71,1.82,1.95$, $2.13\left(5 \mathrm{~m}, 12 \mathrm{H}, \mathrm{OCH}_{2} \mathrm{CH}_{2} \mathrm{CH}_{2} \mathrm{CH}_{2} \mathrm{NH}_{\mathrm{a}}\right.$ and $\left.\mathrm{OCH}_{2} \mathrm{CH}_{2} \mathrm{CH}_{2} \mathrm{CH}_{3}\right), 3.18,4.33(\mathrm{ABq}, 2 \mathrm{H}, \mathrm{J}=13.9 \mathrm{~Hz}$, $\left.\mathrm{ArCH}_{2} \mathrm{Ar}\right), 3.20,4.38\left(\mathrm{ABq}, 2 \mathrm{H}, J=12.7 \mathrm{~Hz}, \mathrm{ArCH}_{2} \mathrm{Ar}\right), 3.21,4.35\left(\mathrm{ABq}, 2 \mathrm{H}, J=12.9 \mathrm{~Hz}, \mathrm{ArCH}_{2} \mathrm{Ar}\right)$, 3.35-3.62, 3.68, 3.76, 3.94 (several m, $12 \mathrm{H}, \mathrm{OCH}_{2} \mathrm{CH}_{2} \mathrm{CH}_{2} \mathrm{CH}_{2} \mathrm{NH}_{\mathrm{a}}$ and $\mathrm{OCH}_{2} \mathrm{CH}_{2} \mathrm{CH}_{2} \mathrm{CH}_{3}$ ), 4.45, 4.54 (ABq, $\left.2 \mathrm{H}, J=13.3 \mathrm{~Hz}, \mathrm{CH}_{2} \mathrm{OCH}_{2}\right), 4.48,4.87\left(\mathrm{ABq}, 2 \mathrm{H}, J=12.8 \mathrm{~Hz}, \mathrm{CH}_{2} \mathrm{OCH}_{2}\right), 6.01,6.05(2 \mathrm{t}, 2 \mathrm{H}$, $\left.\mathrm{NH}_{\mathrm{a}}\right), 6.19,6.69,6.76,6.86,7.11,7.18,7.19,7.24$ (8d, 8H, ArH), 7.29 (t, 1H, Napht), 7.35-7.47 (m, 5H, 
Napht), 7.56, 7.85, 7.97, 8.09 (4d, 5H, Napht), 7.65, 7.69 (2s, 2H, NH $), 7.76$ (m, 3H, Napht); ${ }^{13} \mathrm{C}-\mathrm{NMR}$ $\left(\mathrm{CDCl}_{3}, 125.8 \mathrm{MHz}\right) \delta$ 13.9, $14.1\left(\mathrm{OCH}_{2} \mathrm{CH}_{2} \mathrm{CH}_{2} \mathrm{CH}_{3}\right), 19.35,19.41\left(\mathrm{OCH}_{2} \mathrm{CH}_{2} \mathrm{CH}_{2} \mathrm{CH}_{3}\right), 26.4$, 26.7,

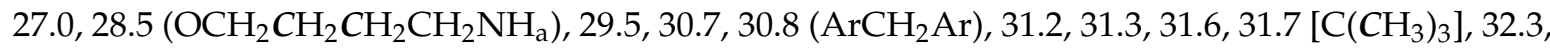
$32.6\left(\mathrm{OCH}_{2} \mathrm{CH}_{2} \mathrm{CH}_{2} \mathrm{CH}_{3}\right), 33.7,33.9,34.15,34.22\left[\mathrm{C}\left(\mathrm{CH}_{3}\right)_{3}\right], 40.3,40.6\left(\mathrm{OCH}_{2} \mathrm{CH}_{2} \mathrm{CH}_{2} \mathrm{CH}_{2} \mathrm{NH}_{\mathrm{a}}\right), 69.2$ (2C) $\left(\mathrm{CH}_{2} \mathrm{OCH}_{2}\right), 73.1,74.0,74.6,75.4\left(\mathrm{OCH}_{2} \mathrm{CH}_{2} \mathrm{CH}_{2} \mathrm{CH}_{2} \mathrm{NH}_{\mathrm{a}}\right.$ and $\left.\mathrm{OCH}_{2} \mathrm{CH}_{2} \mathrm{CH}_{2} \mathrm{CH}_{3}\right), 119.7,121.3$, 121.5, 121.6, 123.6, 124.2 (2C), 124.4, 125.0, 125.2, 125.5, 125.7 (2C), 125.84, 125.87, 125.94, 126.0, 126.3, 126.8, 127.2, 128.3, 128.48 (ArH), 127.6, 128.52, 129.6, 131.8, 132.3, 132.6 (2C), 133.8, 134.1, 134.2 (3C), 134.3, 135.7, 144.4, 145.0, 145.1, 145.2, 152.4, 152.5, 153.0, 153.9 (Ar), 157.1, 157.6 (CO). Anal. Calcd for $\mathrm{C}_{83} \mathrm{H}_{106} \mathrm{~N}_{4} \mathrm{O}_{7}: \mathrm{C}, 78.39 ; \mathrm{H}, 8.40 ; \mathrm{N}, 4.41$. Found: $\mathrm{C}, 77.97 ; \mathrm{H}, 8.68 ; \mathrm{N}, 4.28$.

7,13,19,25-Tetra-tert-butyl-27,29-bis[((N'-1-naphthylthioureido)butyl]oxy]-28,30-dibutoxy-2,3- dihomo-3-

oxa calix[4]arene (5c). Flash chromatography $\left(\mathrm{SiO}_{2}\right.$, eluent $\mathrm{CH}_{2} \mathrm{Cl}_{2} / \mathrm{MeOH}$, from 99.5:0.5 to 97:3); the product obtained was chromatographed again $\left(\mathrm{SiO}_{2}\right.$, eluent $\mathrm{CH}_{2} \mathrm{Cl}_{2} / \mathrm{MeOH}$, from 99.7:0.3 to 97:3), yielding $5 \mathbf{c}$ in $29 \%(0.31 \mathrm{~g})$; m.p. $111-113{ }^{\circ} \mathrm{C} ;{ }^{1} \mathrm{H}-\mathrm{NMR}\left(\mathrm{CDCl}_{3}, 500 \mathrm{MHz}\right) \delta 0.75,1.08,1.11,1.25[4 \mathrm{~s}, 36 \mathrm{H}$, $\left.\mathrm{C}\left(\mathrm{CH}_{3}\right)_{3}\right], 0.87\left(\mathrm{t}, 6 \mathrm{H}, \mathrm{J}=7.45 \mathrm{~Hz}, \mathrm{CH}_{3}\right), 1.23-1.42,1.54-1.87$ (several $\mathrm{m}, 16 \mathrm{H}, \mathrm{OCH}_{2} \mathrm{CH}_{2} \mathrm{CH}_{2} \mathrm{CH}_{3}$ and $\left.\mathrm{OCH}_{2} \mathrm{CH}_{2} \mathrm{CH}_{2} \mathrm{CH}_{2} \mathrm{NH}_{\mathrm{a}}\right), 3.08,4.26\left(\mathrm{ABq}, 2 \mathrm{H}, \mathrm{ArCH}_{2} \mathrm{Ar}\right), 3.08,4.28\left(\mathrm{ABq}, 2 \mathrm{H}, \mathrm{ArCH}_{2} \mathrm{Ar}\right), 3.17,4.24$ (ABq, 2H, $\mathrm{ArCH}_{2} \mathrm{Ar}$ ), 3.43-3.82 (several m, $12 \mathrm{H}, \mathrm{OCH}_{2} \mathrm{CH}_{2} \mathrm{CH}_{2} \mathrm{CH}_{3}$ and $\mathrm{OCH}_{2} \mathrm{CH}_{2} \mathrm{CH}_{2} \mathrm{CH}_{2} \mathrm{NH}_{\mathrm{a}}$ ), 4.30, $4.43\left(\mathrm{ABq}, 2 \mathrm{H}, \mathrm{CH}_{2} \mathrm{OCH}_{2}\right), 4.50,4.53\left(\mathrm{ABq}, 2 \mathrm{H}, \mathrm{CH}_{2} \mathrm{OCH}_{2}\right), 6.02,6,07$ (2t br, 2H, $\left.\mathrm{NH}_{\mathrm{a}}\right), 6.41,6.87$, 6.89, 6.99, 7.06, 7.07 (6d, 8H, ArH), 7.39-7.53 (several m, 8H, Napht), 7.57, 7.62 (2s, 2H, NH $\left.\mathrm{NH}_{\mathrm{b}}\right), 7.82-7.96$ (several m, 6H, Napht); ${ }^{13} \mathrm{C}-\mathrm{NMR}\left(\mathrm{CDCl}_{3}, 125.8 \mathrm{MHz}\right) \delta 14.10,14.12\left(\mathrm{OCH}_{2} \mathrm{CH}_{2} \mathrm{CH}_{2} \mathrm{CH}_{3}\right), 19.26,19.34$ $\left(\mathrm{OCH}_{2} \mathrm{CH}_{2} \mathrm{CH}_{2} \mathrm{CH}_{3}\right), 25.7,25.8,27.3,27.8\left(\mathrm{OCH}_{2} \mathrm{CH}_{2} \mathrm{CH}_{2} \mathrm{CH}_{2} \mathrm{NH}_{\mathrm{a}}\right), 29.7,30.1,30.7\left(\mathrm{ArCH}{ }_{2} \mathrm{Ar}\right), 31.3$, 31.4, 31.51, 31.54 [C( $\left.\left.\mathrm{CH}_{3}\right)_{3}\right], 32.2,32.4\left(\mathrm{OCH}_{2} \mathrm{CH}_{2} \mathrm{CH}_{2} \mathrm{CH}_{3}\right), 33.8,33.9,34.0,34.1\left[\mathrm{C}\left(\mathrm{CH}_{3}\right)_{3}\right], 45.7(2 \mathrm{C})$ $\left(\mathrm{OCH}_{2} \mathrm{CH}_{2} \mathrm{CH}_{2} \mathrm{CH}_{2} \mathrm{NH}_{\mathrm{a}}\right), 68.4,68.5\left(\mathrm{CH}_{2} \mathrm{OCH}_{2}\right), 73.4,73.8,74.1,74.9\left(\mathrm{OCH}_{2} \mathrm{CH}_{2} \mathrm{CH}_{2} \mathrm{CH}_{2} \mathrm{NH}_{\mathrm{a}}\right.$ and $\left.\mathrm{OCH}_{2} \mathrm{CH}_{2} \mathrm{CH}_{2} \mathrm{CH}_{3}\right), 122.5$ (2C), 123.4, 123.6, 124.9, 125.2, 125.3, 125.4, 125.5, 125.7, 125.8, 125.9, 126.2, 126.3, 127.0, 127.1, 127.4, 127.5, 128.5 (2C), 128.9, 129.0 (ArH), 129.96, 130.02, 130.5, 131.5, 131.8, 132.8, 132.9, 133.4, 133.5, 133.7, 134.6, 134.7 (2C), 144.5, 144.9 (2C), 145.1, 152.0, 152.1, 152.5, 153.2 (Ar), 181.6 (CS). Anal. Calcd for $\mathrm{C}_{83} \mathrm{H}_{106} \mathrm{~N}_{4} \mathrm{O}_{5} \mathrm{~S}_{2}$ : C, 74.46; H, 8.19; N, 4.30; S, 4.92. Found: C 75.18; H, 8.72; N, $4.05 ; \mathrm{S}, 4.25$.

3.1.2. Procedure for the Synthesis of Symmetric Urea $\mathbf{5 b}$. Precursor $\mathbf{2} \mathbf{b}$ has Already been Obtained and $\mathbf{3 b}$ and $\mathbf{4 b}$ were Synthesised as Described for $\mathbf{3 a}$ and $\mathbf{4 a}$

7,13,19,25-Tetra-tert-butyl-28,29-bis[(cyanopropyl)oxy]-27,30-dibutoxy-2,3-dihomo-3-oxacalix[4]arene (3b): Flash chromatography $\left(\mathrm{SiO}_{2}\right.$, eluent gradient from $n$-hexane/ethyl acetate 95:5 to 90:10), 61\% yield; $\mathrm{RMN}^{1} \mathrm{H}\left(\mathrm{CDCl}_{3}, 500 \mathrm{MHz}\right) \delta 0.93,1.19\left[2 \mathrm{~s}, 36 \mathrm{H}, \mathrm{C}\left(\mathrm{CH}_{3}\right)_{3}\right], 1.00\left(\mathrm{t}, 6 \mathrm{H}, J=7.4 \mathrm{~Hz}, \mathrm{CH}_{3}\right), 1.45(\mathrm{~m}$, $\left.4 \mathrm{H}, \mathrm{OCH}_{2} \mathrm{CH}_{2} \mathrm{CH}_{2} \mathrm{CH}_{3}\right), 1.76\left(\mathrm{~m}, 4 \mathrm{H}, \mathrm{OCH}_{2} \mathrm{CH}_{2} \mathrm{CH}_{2} \mathrm{CH}_{3}\right), 2.28\left(\mathrm{~m}, 4 \mathrm{H}, \mathrm{OCH}_{2} \mathrm{CH}_{2} \mathrm{CH}_{2} \mathrm{CN}\right), 2.65(\mathrm{~m}$, $\left.4 \mathrm{H}, \mathrm{OCH}_{2} \mathrm{CH}_{2} \mathrm{CH}_{2} \mathrm{CN}\right), 3.24,4.31\left(\mathrm{ABq}, 4 \mathrm{H}, J=13.5 \mathrm{~Hz}, \mathrm{ArCH}_{2} \mathrm{Ar}\right), 3.28,4.26(\mathrm{ABq}, 2 \mathrm{H}, J=13.0 \mathrm{~Hz}$, $\left.\mathrm{ArCH}_{2} \mathrm{Ar}\right), 3.62,3.75\left(2 \mathrm{~m}, 4 \mathrm{H}, \mathrm{OCH}_{2} \mathrm{CH}_{2} \mathrm{CH}_{2} \mathrm{CH}_{3}\right), 3.84,3.91\left(2 \mathrm{~m}, 4 \mathrm{H}, \mathrm{OCH}_{2} \mathrm{CH}_{2} \mathrm{CH}_{2} \mathrm{CN}\right), 4.49,4.68$ $\left(\mathrm{ABq}, 4 \mathrm{H}, J=13.5 \mathrm{~Hz}, \mathrm{CH}_{2} \mathrm{OCH}_{2}\right), 6.66,7.00,7.07$ (3d, 8H, $\left.\mathrm{ArH}\right) ; \mathrm{RMN}^{13} \mathrm{C}\left(\mathrm{CDCl}_{3}, 125,8 \mathrm{MHz}\right) \delta 14.1$ $\left(\mathrm{OCH}_{2} \mathrm{CH}_{2} \mathrm{CH}_{2} \mathrm{CH}_{3}\right), 14.4\left(\mathrm{OCH}_{2} \mathrm{CH}_{2} \mathrm{CH}_{2} \mathrm{CN}\right), 19.3\left(\mathrm{OCH}_{2} \mathrm{CH}_{2} \mathrm{CH}_{2} \mathrm{CH}_{3}\right), 26.1\left(\mathrm{OCH}_{2} \mathrm{CH}_{2} \mathrm{CH}_{2} \mathrm{CN}\right)$, 29.7, $30.3\left(\mathrm{ArCH}_{2} \mathrm{Ar}\right), 31.4\left[\mathrm{C}\left(\mathrm{CH}_{3}\right)_{3}\right], 32.4\left(\mathrm{OCH}_{2} \mathrm{CH}_{2} \mathrm{CH}_{2} \mathrm{CH}_{3}\right), 34.0,34.1\left[\mathrm{C}\left(\mathrm{CH}_{3}\right)_{3}\right], 67.1\left(\mathrm{CH}_{2} \mathrm{OCH}_{2}\right)$, 72.1, $74.9\left(\mathrm{OCH}_{2} \mathrm{CH}_{2} \mathrm{CH}_{2} \mathrm{CN}\right.$ and $\left.\mathrm{OCH}_{2} \mathrm{CH}_{2} \mathrm{CH}_{2} \mathrm{CH}_{3}\right), 119.9(\mathrm{CN}), 123.2,125.6,125.8,126.0(\mathrm{ArH})$, $130.9,132.8,133.3,133.7,145.3,145.6,151.9,152.2(\mathrm{Ar})$.

7,13,19,25-Tetra-tert-butyl-28,29-bis[(aminobutyl)oxy]-27,30-dibutoxy-2,3-dihomo-3-oxacalix[4] arene (4b): $0.83 \mathrm{~g}\left(87 \%\right.$ yield) of product pure enough to be immediately used in the next step; $\mathrm{RMN}{ }^{1} \mathrm{H}$ $\left(\mathrm{CDCl}_{3}, 500 \mathrm{MHz}\right) \delta 0.94,1.18\left[2 \mathrm{~s}, 36 \mathrm{H}, \mathrm{C}\left(\mathrm{CH}_{3}\right)_{3}\right], 1.01\left(\mathrm{t}, 6 \mathrm{H}, J=7.38 \mathrm{~Hz}, \mathrm{CH}_{3}\right), 1.49-1.60(\mathrm{~m}, 8 \mathrm{H}$, $\mathrm{OCH}_{2} \mathrm{CH}_{2} \mathrm{CH}_{2} \mathrm{CH}_{3}$ and $\left.\mathrm{OCH}_{2} \mathrm{CH}_{2} \mathrm{CH}_{2} \mathrm{CH}_{2} \mathrm{NH}_{\mathrm{a}}\right), 1.79\left(\mathrm{~m}, 4 \mathrm{H}, \mathrm{OCH}_{2} \mathrm{CH}_{2} \mathrm{CH}_{2} \mathrm{CH}_{3}\right), 1.98(\mathrm{~m}, 4 \mathrm{H}$, $\left.\mathrm{OCH}_{2} \mathrm{CH}_{2} \mathrm{CH}_{2} \mathrm{CH}_{2} \mathrm{NH}_{\mathrm{a}}\right), 2.78\left(\mathrm{t}, 4 \mathrm{H}, \mathrm{OCH}_{2} \mathrm{CH}_{2} \mathrm{CH}_{2} \mathrm{CH}_{2} \mathrm{NH}_{\mathrm{a}}\right), 3.17,4.40(\mathrm{ABq}, 4 \mathrm{H}, J=13.5 \mathrm{~Hz}$, $\left.\mathrm{ArCH}_{2} \mathrm{Ar}\right), 3.22,4.39\left(\mathrm{ABq}, 2 \mathrm{H}, J=13.0 \mathrm{~Hz}, \mathrm{ArCH}_{2} \mathrm{Ar}\right), 3.60,3.69\left(2 \mathrm{~m}, 4 \mathrm{H}, \mathrm{OCH}_{2} \mathrm{CH}_{2} \mathrm{CH}_{2} \mathrm{CH}_{3}\right), 3.78$, 
$3.84\left(2 \mathrm{~m}, 4 \mathrm{H}, \mathrm{OCH}_{2} \mathrm{CH}_{2} \mathrm{CH}_{2} \mathrm{CH}_{2} \mathrm{NH}_{\mathrm{a}}\right), 4.60,4.66\left(\mathrm{ABq}, 4 \mathrm{H}, \mathrm{J}=13.5 \mathrm{~Hz}, \mathrm{CH}_{2} \mathrm{OCH}_{2}\right), 6.69,6.96,6.97$, $7.05(4 \mathrm{~d}, 8 \mathrm{H}, \mathrm{ArH})$.

7,13,19,25-Tetra-tert-butyl-28,29-bis[[(N'-1-naphthylureido)butyl]oxy]-27,30-dibutoxy-2,3-dihomo

-3-oxacalix[4]arene (5b). To a solution of $\mathbf{4 b}(0.83 \mathrm{~g}, 0.89 \mathrm{mmol})$ in $\mathrm{CHCl}_{3}(35 \mathrm{~mL})$ was added $0.26 \mathrm{~mL}(1.77 \mathrm{mmol})$ of naphthyl isocyanate. The mixture was stirred at room temperature under $\mathrm{N}_{2}$ for $4 \mathrm{~h}$. Evaporation of the solvent yielded the crude product which was purified by flash chromatography $\left(\mathrm{SiO}_{2}\right.$, eluent $\mathrm{CH}_{2} \mathrm{Cl}_{2} / \mathrm{MeOH}$, from 99.7:0.3 to 98:2), followed by recrystallization from $\mathrm{CH}_{2} \mathrm{Cl}_{2} / n$-hexane: it was obtained in $40 \%$ yield $(0.45 \mathrm{~g}) ; \mathrm{mp} 211-213{ }^{\circ} \mathrm{C}$; $\mathrm{IR}(\mathrm{KBr}) 3329 \mathrm{~cm}^{-1}(\mathrm{NH}), 1647$ $\mathrm{cm}^{-1}(\mathrm{CO}) ;{ }^{1} \mathrm{H}-\mathrm{NMR}\left(\mathrm{CDCl}_{3}, 500 \mathrm{MHz}\right) \delta 0.87\left(\mathrm{t}, 6 \mathrm{H}, J=7.35 \mathrm{~Hz}, \mathrm{CH}_{3}\right), 0.95,1.17\left[2 \mathrm{~s}, 36 \mathrm{H}, \mathrm{C}\left(\mathrm{CH}_{3}\right)\right]$, $1.42\left(\mathrm{~m}, 4 \mathrm{H}, \mathrm{OCH}_{2} \mathrm{CH}_{2} \mathrm{CH}_{2} \mathrm{CH}_{3}\right), 1.70\left(\mathrm{~m}, 8 \mathrm{H}, \mathrm{OCH}_{2} \mathrm{CH}_{2} \mathrm{CH}_{2} \mathrm{CH}_{3}\right.$ and $\left.\mathrm{OCH}_{2} \mathrm{CH}_{2} \mathrm{CH}_{2} \mathrm{CH}_{2} \mathrm{NH}_{\mathrm{a}}\right)$, 1.98, $2.06\left(2 \mathrm{~m}, 4 \mathrm{H}, \mathrm{OCH}_{2} \mathrm{CH}_{2} \mathrm{CH}_{2} \mathrm{CH}_{2} \mathrm{NH}_{\mathrm{a}}\right), 3.17,4.33\left(\mathrm{ABq}, 4 \mathrm{H}, \mathrm{J}=13.1 \mathrm{~Hz}, \mathrm{ArCH}_{2} \mathrm{Ar}\right), 3.20,4.39$ (ABq, $\left.2 \mathrm{H}, J=12.9 \mathrm{~Hz}, \mathrm{ArCH}{ }_{2} \mathrm{Ar}\right), 3.34,3.43\left(2 \mathrm{~m}, 4 \mathrm{H}, \mathrm{OCH}_{2} \mathrm{CH}_{2} \mathrm{CH}_{2} \mathrm{CH}_{2} \mathrm{NH}_{\mathrm{a}}\right), 3.56,3.72(2 \mathrm{~m}, 4 \mathrm{H}$, $\left.\mathrm{OCH}_{2} \mathrm{CH}_{2} \mathrm{CH}_{2} \mathrm{CH}_{2} \mathrm{NH}_{\mathrm{a}}\right), 3.74,3.77\left(2 \mathrm{~m}, 4 \mathrm{H}, \mathrm{OCH}_{2} \mathrm{CH}_{2} \mathrm{CH}_{2} \mathrm{CH}_{3}\right), 4.52,4.61(\mathrm{ABq}, 4 \mathrm{H}, J=13.4 \mathrm{~Hz}$, $\left.\mathrm{CH}_{2} \mathrm{OCH}_{2}\right), 5.83\left(\mathrm{t}, 2 \mathrm{H}, \mathrm{NH}_{\mathrm{a}}\right), 6.70,6.95,7.03(3 \mathrm{~d}, 8 \mathrm{H}, \mathrm{ArH}), 7.37,7.38,7.43$ (3t, 6H, Napht), 7.48 (s, 2H, $\left.\mathrm{NH}_{\mathrm{b}}\right), 7.61,7.74,7.81,8.01$ (4d, 8H, Napht); ${ }^{13} \mathrm{C}-\mathrm{NMR}\left(\mathrm{CDCl}_{3}, 125.8 \mathrm{MHz}\right) \delta 14.1\left(\mathrm{OCH}_{2} \mathrm{CH}_{2} \mathrm{CH}_{2} \mathrm{CH}_{3}\right)$, 19.3 $\left(\mathrm{OCH}_{2} \mathrm{CH}_{2} \mathrm{CH}_{2} \mathrm{CH}_{3}\right)$, 27.3, $27.9\left(\mathrm{OCH}_{2} \mathrm{CH}_{2} \mathrm{CH}_{2} \mathrm{CH}_{2} \mathrm{NH}_{\mathrm{a}}\right)$, 30.3, $30.5\left(\mathrm{ArCH} \mathrm{Ar}_{2} \mathrm{Ar}\right), 31.5\left[\mathrm{C}\left(\mathrm{CH}_{3}\right)_{3}\right]$, $32.6\left(\mathrm{OCH}_{2} \mathrm{CH}_{2} \mathrm{CH}_{2} \mathrm{CH}_{3}\right)$, $34.0\left[\mathrm{C}\left(\mathrm{CH}_{3}\right)_{3}\right], 40.7\left(\mathrm{OCH}_{2} \mathrm{CH}_{2} \mathrm{CH}_{2} \mathrm{CH}_{2} \mathrm{NH}_{\mathrm{a}}\right), 67.4\left(\mathrm{CH}_{2} \mathrm{OCH}_{2}\right)$, 74.21, $74.24\left(\mathrm{OCH}_{2} \mathrm{CH}_{2} \mathrm{CH}_{2} \mathrm{CH}_{2} \mathrm{NH}_{\mathrm{a}}\right.$ and $\left.\mathrm{OCH}_{2} \mathrm{CH}_{2} \mathrm{CH}_{2} \mathrm{CH}_{3}\right), 121.1,121.6,123.2,125.2,125.56,125.59$, 125.61, 125.97, 126.04, 126.1, 128.5 (ArH), 128.2, 131.0, 133.2, 133.3, 133.7, 134.1, 134.4, 144.8, 145.0, 152.3, 153.0 (Ar), 157.3 (CO). Anal. Calcd for $\mathrm{C}_{83} \mathrm{H}_{106} \mathrm{~N}_{4} \mathrm{O}_{7}$ : C, 78.39; H, 8.40; N, 4.41. Found: C,78.51: $\mathrm{H}$, $8.38 ; \mathrm{N}, 4.40)$.

\subsection{Determination of the Crystallographic Structures of $5 \boldsymbol{a}$ and $\mathbf{5 b}$}

Single crystals suitable for an X-ray investigation were obtained by slow evaporation of solutions containing compound $\mathbf{5 a}$ and $\mathbf{5 b}$ using dichloromethane/ethanol solvent mixtures. Data collection was carried out at the XRD1 beamline of the Elettra synchrotron (Trieste, Italy), employing the rotating-crystal method with a Dectris Pilatus 2M area detector (DECTRIS Ltd., Baden-Daettwil, Switzerland). Single crystals were dipped in paratone cryoprotectant, mounted on a loop and flash-frozen under a liquid nitrogen stream at a $100 \mathrm{~K}$. Diffraction data were indexed and integrated using the XDS package [36], while scaling was carried out with XSCALE [37]. Structures was solved using the SHELXT program [38] and structure refinement was performed with SHELXL-14 [39], operating through the WinGX GUI [40], by full-matrix least-squares (FMLS) methods on $\mathrm{F}^{2}$. Non-hydrogen atoms with occupancy of more than $50 \%$ were anisotropically refined, while non-hydrogen atoms with a lower occupancy were refined isotropically. Hydrogen atoms were added at the calculated positions and refined using the riding model. Crystallographic data and refinement details are reported in Table S6.

\subsection{H-NMR Titrations}

The anion association constants (as log $K_{\text {ass }}$ ) were determined in $\mathrm{CDCl}_{3}$ by ${ }^{1} \mathrm{H}-\mathrm{NMR}$ titration experiments. Several aliquots (up to 10 equiv.) of the anion solutions (as TBA salts) were added to $0.5 \mathrm{~mL}$ solution of the receptors $\left(2.5 \times 10^{-3}-5 \times 10^{-3} \mathrm{M}\right)$ directly in the NMR tube. The spectra were recorded after each addition of the salts, and the temperature of the NMR probe was kept constant at $25{ }^{\circ} \mathrm{C}$. The association constants were evaluated using the WinEQNMR2 program [26] and following the urea NH chemical shifts. The Job methods were performed keeping the total concentration in the same range as before. In the case of ion-pair recognition studies, the percentage of complexation was determined by direct ${ }^{1} \mathrm{H}-\mathrm{NMR}$ integration of the free and complexed peaks of the hosts and/or the guests, present at equilibrium. The samples were prepared by mixing aliquots of stock solutions of the host $(600 \mu \mathrm{L})$ and guests $(60 \mu \mathrm{L})$ to obtain a final equimolar host-guest solution of $1.0 \times 10^{-3} \mathrm{M}$. For each host-guest system titrations were repeated at least two times. Details related to these experiments have already been described [20]. 


\subsection{UV-Vis Absorption and Fluorescence Studies}

Absorption and fluorescence studies were done using an UV-3101PC UV-Vis-NIR spectrophotometer (Shimadzu, Kyoto, Japan) and a Fluorolog F112A fluorimeter (Spex Industries, Edison, NJ, USA) in right-angle configuration, respectively. The association constants were determined in $\mathrm{CH}_{2} \mathrm{Cl}_{2}$ by $\mathrm{UV}$-Vis absorption spectrophotometry and by steady-state fluorescence at $25{ }^{\circ} \mathrm{C}$. The absorption spectra were recorded between 260 and $370 \mathrm{~nm}$ and the emission ones between 325 and $550 \mathrm{~nm}$, and using quartz cells with an optical path length of $1 \mathrm{~cm}$. Several aliquots (up to 10 equiv) of the anion solutions (as TBA salts) were added to a $2 \mathrm{~mL}$ solution of the receptors $\left(3.0 \times 10^{-5}-5.0 \times 10^{-5} \mathrm{M}\right)$ directly in the cell. The spectral changes were interpreted using the HypSpec 2014 program [41]. Details concerning the photophysical properties determination has already been described [23].

\subsection{Quantum Chemistry Calculations}

Stationary points were optimized with the Gaussian 09 program [42] with the B3LYP [43] density functional with the 6-31G(d,p) basis set. A D3-Grimme correction [44] was also used. Experimental X-ray diffraction structure determinations were employed as the starting structures for the calixarene hosts and different starting positions for the ions were used for the geometry optimization. All reported structures were confirmed as energy minima, with no negative eigenvalue in the Hessian matrix. The structures and energies given are the most stable conformations obtained after optimization. The interaction energy $\Delta E$ between the calixarenes and the ions $(\Delta E=E$ (complex) $-E$ (free calix) $-E$ (ion) $)$ was calculated with respect to the optimized geometries of all species.

\section{Conclusions}

New fluorescent dihomooxacalix[4]arene receptors containing two (thio)urea moieties in distal and proximal positions (1,3-dinaphthylurea 5a, 3,4-dinaphthylurea $\mathbf{5 b}$ and 1,3-dinaphthylthiourea 5c) at the lower rim linked by a butyl spacer were obtained in the cone conformation in solution. The X-ray structures of $\mathbf{5 a}$ and $\mathbf{5 b}$ were reported and revealed only small differences in the cone conformation. The main difference in the structures is ascribable to the mutual orientation of the naphthyl rings of the ureido substituents, which are almost parallel in $\mathbf{5 a}$ and almost perpendicular in 5 b. Both crystal structures are characterized by intra- and inter-molecular bifurcated H-bonds involving the ureido groups. The anion binding affinity of these derivatives was established by ${ }^{1} \mathrm{H} N M R$, UV-Vis, fluorescence and DFT studies. 1:1 complexes between anions of different geometries and the receptors through hydrogen bonding were obtained. The results revealed that for all receptors the association constants increase with the anion basicity, and the strongest complexes were obtained with $\mathrm{F}^{-}$, followed by the carboxylates $\mathrm{AcO}^{-}$and $\mathrm{BzO}^{-}$. Symmetric urea $\mathbf{5 b}$ is a better anion receptor compared to the asymmetric urea $\mathbf{5 a}$, as shown by all the spectroscopic techniques used and corroborated by the quantum mechanical calculations. Both ureido compounds are more efficient than thiourea 5c. As ditopic receptors, ureas $5 \mathbf{a}$ and $5 \mathbf{b}$ showed a very high affinity for the guests $n-\mathrm{PrNH}_{3}{ }^{+} \cdot \mathrm{Cl}^{-}$ and $n-\mathrm{BuNH}_{3}{ }^{+} \cdot \mathrm{Cl}^{-}\left(K_{\text {ass }}=1.0 \times 10^{4}-2.9 \times 10^{4} \mathrm{M}^{-2}\right.$ in $\left.\mathrm{CDCl}_{3} / \mathrm{DMSO}_{6}, 5: 1\right)$, as well as for the neurotransmitter GABA $\cdot \mathrm{HCl}\left(K_{\text {ass }}=2.2 \times 10^{4}\right.$ and $6.0 \times 10^{4} \mathrm{M}^{-2}$ respectively, in $\mathrm{CDCl}_{3} / \mathrm{CD}_{3} \mathrm{OD}$, 5:1). The bulkier $\mathrm{CH}_{3}$ groups of the betaine guest prevented its inclusion inside the macrocycle cavity. Concerning chiral recognition, the enantiopure $(R)$-sec- $\mathrm{BuNH}_{3}{ }^{+} \cdot \mathrm{Cl}^{-}$guest displayed a $5: 2$ selectivity towards $(P)$ and $(M)$ enantiomers of the inherently chiral host $5 \mathbf{a}$. Based on DFT calculations, the $\left[(S)-\mathrm{sec}-\mathrm{BuNH}_{3}{ }^{+} \cdot \mathrm{Cl}^{-} /(M)-5 \mathbf{a}\right]$ complex was deduced as the more stable.

Supplementary Materials: The following are available online: Crystallographic data and refinement details; titration curves with TBA salts in $\mathrm{CDCl}_{3}$; Job's plots; absorption and emission spectra with TBA salts; COSY spectra of $\mathbf{5 a}+\mathrm{GABA} \cdot \mathrm{HCl}$ and $\mathbf{5 a}+\sec -\mathrm{BuNH}_{2} \cdot \mathrm{HCl} ;{ }^{1} \mathrm{H},{ }^{13} \mathrm{C}$ and $\mathrm{COSY}$ spectra of compounds $\mathbf{3 b}, \mathbf{5 a}, \mathbf{5 b}$ and $\mathbf{5} \mathbf{c}$.

Author Contributions: A.S.M.: investigation, acquisition and analysis of data, editing. P.M.M.: conceptualization, supervision, acquisition, analysis and interpretation of data, writing, review and editing. J.R.A.: analysis and interpretation of NMR data, writing and review. M.N.B.-S.: analysis, interpretation and writing of photophysics 
data. R.S.: performance of DFT calculations, analysis and writing. N.H. and S.G.: analysis of structural data, writing and review. All authors have read and agreed to the published version of the manuscript.

Funding: Authors thank Fundação para a Ciência e a Tecnologia, Projects ref. UID/QUI/00100/2013, UIDB/00100/2020 and UIDB/04565/2020; A. S. Miranda thanks a PhD Grant ref. SFRH/BD/129323/2017.

Conflicts of Interest: The authors declare no conflict of interest.

\section{References and Notes}

1. Gutsche, C.D. Calixarenes: An Introduction: Edition 2, 2nd ed.; The Royal Society of Chemistry: Cambridge, UK, 2008; Monographs in Supramolecular Chemistry.

2. Neri, P.; Sessler, J.L.; Wang, M.-X. Calixarenes and Beyond; Springer International Publishing: Cham, Switzerland, 2016.

3. Kumar, R.; Jung, Y.; Kim, J.S. Fluorescent calixarene hosts. In Calixarenes and Beyond; Neri, P., Sessler, J.L., Wang, M.-X., Eds.; Springer International Publishing: Cham, Switzerland, 2016; pp. 743-760.

4. Kumar, R.; Sharma, A.; Singh, H.; Suating, P.; Kim, H.S.; Sunwoo, K.; Shim, I.; Gibb, B.C.; Kim, J.S. Revisiting fluorescent calixarenes: From molecular sensors to smart materials. Chem. Rev. 2019, 119, 9657-9721. [CrossRef]

5. Kim, S.K.; Bok, J.H.; Bartsch, R.A.; Lee, J.Y.; Kim, J.S. A fluoride-selective PCT chemosensor based on formation of a static pyrene excimer. Org. Lett. 2005, 7, 4839-4842. [CrossRef] [PubMed]

6. Jeon, N.J.; Ryu, B.J.; Lee, B.H.; Nam, K.C. Fluorescent sensing of tetrahedral anions with a pyrene urea derivative of calix[4]arene chemosensor. Bull. Kor. Chem. Soc. 2009, 30, 1675-1677.

7. Ryu, B.J.; Jeon, N.J.; Nam, K.C. 1,3-Alternate calix[4]arene bifuntional fluorescent receptor containing urea and crown ether moieties. Bull. Korean Chem. Soc. 2010, 31, 3445-3447. [CrossRef]

8. Patra, S.; Gunupuru, R.; Lo, R.; Suresh, E.; Ganguly, B.; Paul, P. Cation-induced fluorescent excimer emission in calix[4]arene-chemosensors bearing quinoline as a fluorogenic unit: Experimental, molecular modeling and crystallographic studies. New J. Chem. 2012, 36, 988-1002. [CrossRef]

9. Sutariya, P.G.; Pandya, A.; Lodha, A.; Menon, S.K. A pyrenyl linked calix[4]arene fluorescence probe for recognition of ferric and phosphate ions. RSC Advances 2014, 4, 34922-34926. [CrossRef]

10. Uttam, B.; Kandi, R.; Hussain, M.A.; Rao, C.P. Fluorescent lower rim 1,3-dibenzooxadiazole conjugate of calix[4]arene in selective sensing of fluoride in solution and in biological cells using confocal microscopy. J. Org. Chem. 2018, 83, 11850-11859. [CrossRef]

11. Capici, C.; De Zorzi, R.; Gargiulli, C.; Gattuso, G.; Geremia, S.; Notti, A.; Pappalardo, S.; Parisi, M.F.; Puntoriero, F. Calix[5]crown-3-based heteroditopic receptors for n-butylammonium halides. Tetrahedron 2010, 66, 4987-4993. [CrossRef]

12. Jeon, N.J.; Ryu, B.J.; Park, K.D.; Lee, Y.J.; Nam, K.C. Tetrahedral anions selective fluorescent calix[6]arene receptor containing urea and pyrene moieties. Bull. Korean Chem. Soc. 2010, 31, 3809-3811. [CrossRef]

13. Brunetti, E.; Picron, J.-F.; Flidrova, K.; Bruylants, G.; Bartik, K.; Jabin, I. Fluorescent chemosensors for anions and contact ion pairs with a cavity-based selectivity. J. Org. Chem. 2014, 79, 6179-6188.

14. Brunetti, E.; Moerkerke, S.; Wouters, J.; Bartik, K.; Jabin, I. A selective calix[6]arene-based fluorescent chemosensor for phosphatidylcholine type lipids. Org. Biomol. Chem. 2016, 14, 10201-10207. [CrossRef] [PubMed]

15. Busschaert, N.; Caltagirone, C.; Van Rossom, W.; Gale, P.A. Applications of supramolecular anion recognition. Chem. Rev. 2015, 115, 8038-8155. [CrossRef] [PubMed]

16. Gale, P.A.; Howe, E.N.W.; Wu, X. Anion receptor chemistry. Chem 2016, 1, 351-422. [CrossRef]

17. Kim, S.K.; Sessler, J.L. Ion pair receptors. Chem. Soc. Rev. 2010, 39, 3784-3809. [CrossRef] [PubMed]

18. McConnell, A.J.; Beer, P.D. Heteroditopic receptors for ion-pair recognition. Angew. Chem. Int. Ed. 2012, 51, 5052-5061. [CrossRef] [PubMed]

19. Marcos, P.M.; Teixeira, F.A.; Segurado, M.A.P.; Ascenso, J.R.; Bernardino, R.J.; Michel, S.; Hubscher-Bruder, V. Bidentate urea derivatives of $p$-tert-butyldihomooxacalix[4]arene: Neutral receptors for anion complexation. J. Org. Chem. 2014, 79, 742-751. [CrossRef]

20. Gattuso, G.; Notti, A.; Parisi, M.F.; Pisagatti, I.; Marcos, P.M.; Ascenso, J.R.; Brancatelli, G.; Geremia, S. Selective recognition of biogenic amine hydrochlorides by heteroditopic dihomooxacalix[4]arenes. New J. Chem. 2015, 39, 817-821. [CrossRef] 
21. Teixeira, F.A.; Marcos, P.M.; Ascenso, J.R.; Brancatelli, G.; Hickey, N.; Geremia, S. Selective binding of spherical and linear anions by tetraphenyl(thio)urea-based dihomooxacalix[4]arene receptors. J. Org. Chem. 2017, 82, 11383-11390. [CrossRef]

22. Augusto, A.S.; Miranda, A.S.; Ascenso, J.R.; Miranda, M.Q.; Félix, V.; Brancatelli, G.; Hickey, N.; Geremia, S.; Marcos, P.M. Anion recognition by partial cone dihomooxacalix[4]arene-based receptors bearing urea groups: Remarkable affinity for benzoate ion. Eur. J. Org. Chem. 2018, 2018, 5657-5667. [CrossRef]

23. Miranda, A.S.; Serbetci, D.; Marcos, P.M.; Ascenso, J.R.; Berberan-Santos, M.N.; Hickey, N.; Geremia, S. Ditopic receptors based on dihomooxacalix[4]arenes bearing phenylurea moieties with electron-withdrawing groups for anions and organic ion pairs. Front. Chem. 2019, 7, 758. [CrossRef]

24. Miranda, A.S.; Martelo, L.M.; Fedorov, A.A.; Berberan-Santos, M.N.; Marcos, P.M. Fluorescence properties of p-tert-butyldihomooxacalix[4]arene derivatives and the effect of anion complexation. New J. Chem. 2017, 41, 5967-5973. [CrossRef]

25. Jaime, C.; de Mendoza, J.; Prados, P.; Nieto, P.; Sanchez, C. Carbon-13 NMR chemical shifts. A single rule to determine the conformation of calix[4]arenes. J. Org. Chem. 1991, 56, 3372-3376. [CrossRef]

26. Hynes, M.J. EQNMR: A computer program for the calculation of stability constants from nuclear magnetic resonance chemical shift data. J.Chem. Soc., Dalton Trans. 1993, 311-312. [CrossRef]

27. Stibor, I.; Budka, J.; Michlova, V.; Tkadlecova, M.; Pojarova, M.; Curinova, P.; Lhotak, P. Systematic approach to new ligands for anion recognition based on ureido-calix[4]arenes. New J. Chem. 2008, 32, 1597-1607. [CrossRef]

28. Marcos, P.M.; Teixeira, F.A.; Segurado, M.A.P.; Ascenso, J.R.; Bernardino, R.J.; Brancatelli, G.; Geremia, S. Synthesis and anion binding properties of new dihomooxacalix[4]arene diurea and dithiourea receptors. Tetrahedron 2014, 70, 6497-6505. [CrossRef]

29. Teixeira, F.A.; Ascenso, J.R.; Cragg, P.J.; Hickey, N.; Geremia, S.; Marcos, P.M. Recognition of anions, monoamine neurotransmitter and trace amine hydrochlorides by ureido-hexahomotrioxacalix[3]arene ditopic receptors. Eur. J. Org. Chem. 2020, 1930-1940. [CrossRef]

30. Scheerder, J.; Fochi, M.; Engbersen, F.J.; Reinhoudt, D.N. Urea-derivatized p-tert-butylcalix[4]arenes: Neutral ligands for selective anion complexation. J. Org. Chem. 1994, 59, 7815-7820. [CrossRef]

31. Hamon, M.; Ménand, M.; Le Gac, S.; Luhmer, M.; Dalla, V.; Jabin, I. Calix[6]tris(thio)ureas: Heteroditopic receptors for the cooperative binding of organic ion pairs. J. Org. Chem. 2008, 73, 7067-7071.

32. Bryantsev, V.S.; Hay, B.P. Conformational preferences and internal rotation in alkyl- and phenyl-substituted thiourea derivatives. J. Phys. Chem. A 2006, 110, 4678-4688. [CrossRef]

33. Mei, M.; Wu, S. Fluorescent sensor for $\alpha, \omega$-dicarboxylate anions. New J Chem. 2001, 25, 471-475. [CrossRef]

34. Gaeta, C.; Talotta, C.; Farina, F.; Teixeira, F.A.; Marcos, P.M.; Ascenso, J.R.; Neri, P. Alkylammonium cation complexation into the narrow cavity of dihomooxacalix[4]arene macrocycle. J. Org. Chem. 2012, 77, 10285-10293. [CrossRef] [PubMed]

35. Due to the inherent chirality of dihomooxacalix[4]arenes, $(P)$ and $(M)$ descriptors were used as an alternative to the usual $(R)$ and $(S)$ notation. For this subject see: (a) Szumna, A. Inherently chiral concave molecules from synthesis to applications. Chem. Soc. Rev. 2010, 39, 4274-4285. (b) ref 22.

36. Kabsch, W. XDS. Acta Crystallogr. Sect. D Biol. Crystallogr. 2010, 66, 125-132. [CrossRef] [PubMed]

37. Kabsch, W. Integration, scaling, space-group assignment and post-refinement. Acta Crystallogr. Sect. D Biol. Crystallogr. 2010, 66, 133-144. [CrossRef] [PubMed]

38. Sheldrick, G.M. SHELXT-Integrated space-group and crystal-structure determination. Acta Crystallog. Sect. A Found. Crystallogr. 2015, 71, 3-8. [CrossRef] [PubMed]

39. Sheldrick, G.M. A short history of SHELX. Acta Crystallog. Sect. A Found. Crystallogr. 2008, 64, 112-122. [CrossRef] [PubMed]

40. Farrugia, L.J. WinGX and ORTEP for Windows: An update. J. Appl. Crystallog. 2012, 45, 849-854. [CrossRef]

41. Gans, P.; Sabatini, A.; Vacca, A. Investigation of equilibria in solution. Determination of equilibrium constants with the HYPERQUAD suite of programs. Talanta 1996, 43, 1739-1753. [CrossRef]

42. Frisch, M.J.; Trucks, G.W.; Schlegel, H.B.; Scuseria, G.E.; Robb, M.A.; Cheeseman, J.R.; Scalmani, G.; Barone, V.; Mennucci, B.; Petersson, G.A.; et al. Gaussian 09 Rev. D.01; Gaussian Inc.: Wallingford, CT, UAS, 2016.

43. Becke, A.D. Density-functional thermochemistry. III. The role of exact exchange. J. Chem. Phys. 1993, 98, 5648-5652. [CrossRef] 
44. Grimme, S.; Antony, J.; Ehrlich, S.; Krieg, H. A consistent and accurate ab initio parametrization of density functional dispersion correction (DFT-D) for the 94 elements H-Pu. J. Chem. Phys. 2010, 132, 154104. [CrossRef]

Sample Availability: Samples of the compounds are not available from the authors.

Publisher's Note: MDPI stays neutral with regard to jurisdictional claims in published maps and institutional affiliations.

(C) 2020 by the authors. Licensee MDPI, Basel, Switzerland. This article is an open access article distributed under the terms and conditions of the Creative Commons Attribution (CC BY) license (http://creativecommons.org/licenses/by/4.0/). 